\title{
Distinct chitinases are expressed during various growth phases of the human pathogen Paracoccidioides brasiliensis
}

\author{
Lidiane Aparecida da Penha Santana', Marilene Henning Vainstein², Patrícia Kott Tomazett ${ }^{1}$ \\ Ludier Kesser Santos-Silva', Alfredo Miranda Góes ${ }^{3}$, Augusto Schrank², \\ Célia Maria de Almeida Soares ${ }^{1}$, Maristela Pereira ${ }^{1 /+}$ \\ 'Laboratório de Biologia Molecular, Instituto de Ciências Biológicas, Universidade Federal de Goiás, Goiânia, GO, Brasil \\ ${ }^{2}$ Centro de Biotecnologia, Universidade Federal do Rio Grande do Sul, Porto Alegre, RS, Brasil \\ ${ }^{3}$ Departamento de Bioquímica e Imunologia, Universidade Federal de Minas Gerais, Belo Horizonte, MG, Brasil
}

The aim of this work was the partial purification and subsequent evaluation of chitinase expression during the various growth phases of Paracoccidioides brasiliensis. Initially, PbCTSIr was expressed as a recombinant protein and displayed enzymatic activity against 4-MU-[N-acetylglucosamine (GlcNAc) $]_{3}$ and 4-MU-(GlcNAc) ${ }_{2}$. Two proteins, $45 \mathrm{kDa}$ and $39 \mathrm{kDa}$ in size, were partially purified from $\mathrm{P}$. brasiliensis yeast crude extract using cationexchange chromatography coupled with HPLC and were characterised as $\mathrm{PbCTS1}$ and $\mathrm{PbCTS2}$, respectively. Anti$\mathrm{PbCTSIr}$ antibody recognised two proteins in the crude extracts of yeast and the transitional stage between mycelial and yeast phases. In crude extracts of mycelium, only the $45 \mathrm{kDa}$ protein was detected. However, quantitative realtime polymerase chain reaction led to the detection of small quantities of Pbcts 2 transcript in the mycelial phase. In the yeast cell wall extract, only the $39 \mathrm{kDa}$ protein was detected. Moreover, both proteins were secreted by the yeast parasitic phase, suggesting that these proteins participate in the modulation of the fungal environment. Phylogenetic analysis of the predicted $\mathrm{PbCTS1}$ and $\mathrm{PbCTS} 2$ proteins indicated that they code for distinct chitinases in $\mathrm{P}$. brasiliensis. During evolution, P. brasiliensis could have acquired the paralogues Pbcts1 and Pbcts 2 for growth and survival in diverse environments in both saprophytic and parasitic phases.

Key words: Paracoccidioides - chitinase - cell wall - chromatography

Paracoccidioides brasiliensis is a dimorphic fungus pathogenic to humans, growing as yeast during infection and as mycelium in the environment. The cell wall of $P$. brasiliensis consists of chitin and glucan and is involved in pathogenesis (de Agostino Biella et al. 2006). The percentage of chitin in $P$. brasiliensis ranges from $37-48 \%$ in the yeast phase and from $7-18 \%$ in the mycelial phase, indicating the importance of this carbohydrate and the enzymes involved in cell wall metabolism in dimorphism and the fungal infection process (Kanetsuna et al. 1969).

Chitin is a polymer of $\beta$-1.4-linked N-acetylglucosamine (GlcNAc) and is the major structural component of crustacean exoskeletons, insect cuticles, diatoms and fungal cell walls, but it is not present in humans (Barrett 2002). Due to its absence in humans, chitinases have been examined as interesting targets in the exploratory design of specific antifungal agents (Rush et al. 2010).

Chitinases (EC 3.2.1.14) hydrolyse chitin and can be classified into two families of glycoside hydrolases, families 18 and 19, based on amino acid sequence, structural homology and mechanism of action (Henrissat \& Bairoch 1996). Furthermore, chitinolytic enzymes can be divided

Financial support: CNPq, CAPES (to LAPS and LKS-S), FINEP, PROCAD, IFS (to MP)

+Corresponding author: mani@icb.ufg.br

Received 15 May 2011

Accepted 1 February 2012 into two major categories based on their mode of action: endochitinases and exochitinases. Endochitinases (EC 3.2.1.14) cleave chitin and chito-oligomers and release multimers of GlcNAc. Exochitinases can be divided into two subcategories: chitin 1.4- $\beta$-chitobiosidases and $\beta-\mathrm{N}$ acetylhexosaminidases. Chitin 1.4- $\beta$-chitobiosidases are not officially recognised with an EC number. They cleave chitin and chito-oligomers and release only (GlcNAc). $\beta$-N-acetylhexosaminidases (EC 3.2.1.52) release only GlcNAc monomers (Lorito 1998).

Fungal chitinases are important for nutrition, developmental processes, morphogenesis and pathogenesis (Dahiya et al. 2006, Binod et al. 2007). Many fungal chitinases have been purified and characterised and most fungi express more than one chitinolytic enzyme (Seidl et al. 2005, Duo-Chuan 2006).

In this work, our aim was to partially purify chitinases from $P$. brasiliensis and to evaluate their expression during different growth phases, including mycelium, yeast and the transition from mycelium to yeast, in addition to the cell wall of yeast and the supernatant of the yeast culture medium.

\section{MATERIALS AND METHODS}

Fungus and growth conditions - P. brasiliensis, Pb01 isolate (ATCC-MYA-826), was cultivated in modified Sabouraud dextrose solid medium (4\% glucose, $1 \%$ peptone, $0.5 \%$ yeast extract, $0.1 \%$ brain-heart infusion, $1.2 \%$ agar) at $22^{\circ} \mathrm{C}$ for 15 days for the mycelial phase and at $36^{\circ} \mathrm{C}$ for seven days for the yeast phase. For the transition from mycelium to yeast, the fungus growing at $22^{\circ} \mathrm{C}$ 
was transferred to liquid medium at $36^{\circ} \mathrm{C}$ and grown for $24 \mathrm{~h}$ under shaking at $150 \mathrm{rpm}$.

Recombinant DNA preparation and transformation - The Pbcts1 cDNA (accession AQ75798) (Bonfim et al. 2006) was amplified by polymerase chain reaction (PCR) using forward (5'-CAGATCCACCAGAATTCATGACG-3') and reverse (5'-CACCTCGAGCTACTCCCCAGG-3') primers containing EcoRI and XhoI sites (underlined), respectively, for cloning into the expression vector pET-32a $(+)$ (Novagen). PCR conditions were as follows: $94^{\circ} \mathrm{C}(3 \mathrm{~min}), 25$ cycles at $94^{\circ} \mathrm{C}(1 \mathrm{~min}$ and $30 \mathrm{~s})$, $58^{\circ} \mathrm{C}(2 \mathrm{~min})$ and $72^{\circ} \mathrm{C}(1 \mathrm{~min}$ and $30 \mathrm{~s})$ and a final elongation at $72^{\circ} \mathrm{C}(10 \mathrm{~min})$. The PCR product was digested with $E c o$ RI and $X h o I$ and cloned into the respective sites of pET-32a $(+)$. The resulting plasmid was used to transform Escherichia coli BL21(DE3)/pLysS (Certificate of Quality in Biosafety 0037-97).

Production and purification of the recombinant protein - The transformed $E$. coli cells were grown at $37^{\circ} \mathrm{C}$ in LB-medium with $34 \mu \mathrm{g} \mathrm{mL}-1$ chloramphenicol, $100 \mu \mathrm{g} \mathrm{mL}^{-1}$ ampicillin and $200 \mathrm{mM}$ glucose at $200 \mathrm{rpm}$ until the $\mathrm{A}_{600}$ reached 0.6-0.8. Expression was induced by the addition of isopropyl- $\beta$-D-thiogalactopyranoside (IPTG) at a final concentration of $1 \mathrm{mM}$. The cells were incubated for $3 \mathrm{~h}$ at $37^{\circ} \mathrm{C}$ with shaking at $200 \mathrm{rpm}$, followed by centrifugation at $10,000 \mathrm{~g}$ for $5 \mathrm{~min}$ at $4^{\circ} \mathrm{C}$. The cell pellet containing insoluble inclusion bodies was suspended in phosphate buffered saline (PBS), incubated for $1 \mathrm{~h}$ with lysozyme $\left(1 \mathrm{mg} \mathrm{mL}^{-1}\right)$ and sonicated, and $1 \%$ sarkosyl was added. The sample was centrifuged at $10,000 \mathrm{~g}$ for $20 \mathrm{~min}$ at $4^{\circ} \mathrm{C}$, following which $2 \%$ Triton $\mathrm{X}-100$ was added to the supernatant. The recombinant chitinase $(P b C T S 1 r)$ was purified using Ni-NTA resin (Invitrogen). Briefly, the supernatant was applied on a Ni-NTA resin column and $P b C T S 1 r$ was recovered using elution buffer [ $250 \mathrm{mM}$ imidazole, $0.5 \mathrm{M}$ sodium chloride $(\mathrm{NaCl}), 50 \mathrm{mM}$ sodium phosphate, $\mathrm{pH}$ 8.0]. For later assays, the affinity-purified fusion protein was pooled, dialysed in sodium acetate buffer at pH 6.0 and hydrolysed with enterokinase.

Antibody production - PbCTS1r was used to produce anti- $P b C$ CS1r antibody in New Zealand rabbits. The immunisation consisted of three injections of $200 \mu \mathrm{g}$ of $P b C T S 1 r$, with an interval of two weeks between injections. The serum containing anti- $P b C T S 1 r$ antibody was collected and ELISA and Western blotting were used to test antibody reactivity. The protocol concerning animal immunisation was approved by the local Ethical Committee on Animal Care of Federal University of Minas Gerais (protocol CETEA-UFMG 043/2008).

Protein extraction - Protein extracts from mycelium, yeast cells, the transition from mycelium to yeast and the cell wall of the yeast were obtained by disruption of frozen $P$. brasiliensis cells. The cells were resuspended in Tris-Ca buffer $\left[2 \mathrm{mM} \mathrm{CaCl}_{2}, 20 \mathrm{mM}\right.$ Tris-HCl, $\mathrm{pH}$ 8.8; protease inhibitor (GE-Healthcare)], harvested and shaken for $20 \mathrm{~min}$ at $4^{\circ} \mathrm{C}$ with glass beads. Complete cell disruption was verified by the absence of fungal growth on Sabouraud medium. Lysed cells were separated into two fractions, the cell wall (pellet) and a crude protein extract (supernatant), using centrifugation at 5,000 $g$ and $4^{\circ} \mathrm{C}$ for $15 \mathrm{~min}$. The pellet was washed five times with distilled water, rinsed with varying concentrations of $\mathrm{NaCl}(85 \mathrm{mM} ; 34 \mathrm{mM} ; 17 \mathrm{mM})$ and boiled in sodium dodecyl sulfate (SDS)-extraction buffer $(50 \mathrm{mM}$ Tris- $\mathrm{HCl}$, $\mathrm{pH}$ 8.0, 2\% SDS, $100 \mathrm{mM}$ EDTA, $10 \mathrm{mM}$ DTT) for 10 min. This treatment was repeated twice to ensure complete liberation of the SDS-solubilised proteins. Finally, the pellet was washed six times with water, resuspended in Tris-Ca buffer and stored as an extract composed of cell wall proteins (Pitarch et al. 2002).

Yeast-secreted proteins were obtained by filtration $(0.22 \mu \mathrm{m}$ filter) of Sabouraud dextrose medium containing $P$. brasiliensis yeast grown for $24 \mathrm{~h}$. The protein extract was dialysed against distilled water and precipitated with $20 \%$ trichloroacetic acid and acetone.

Purification of native chitinases from P. brasiliensis - The soluble protein crude extract of yeast cells was consecutively dialysed against distilled water and 50 $\mathrm{mM}$ sodium acetate buffer, $\mathrm{pH} 5.4$ (buffer A), filtered through a $0.22 \mu \mathrm{m}$ filter and applied to a CM SepharoseTM Fast Flow column pre-equilibrated with buffer A (HPLC Äkta purifier GE-Healthcare). The proteins were eluted with a linear gradient of buffer A containing 0-1 $\mathrm{M} \mathrm{NaCl}$ with a flow rate of $1 \mathrm{~mL} \mathrm{~min}{ }^{-1}$. Fractions of 1 $\mathrm{mL}$ and $0.5 \mathrm{~mL}$ fractions were collected before and after the application of the $\mathrm{NaCl}$ gradient, respectively. The fractions were dialysed against distilled water and their chitinase activity was determined.

Electrophoresis and protein quantification - SDSpolyacrylamide gel electrophoresis (SDS-PAGE) was performed under denaturing conditions, as described by Laemmli (1970). Proteins were separated by $10 \%$ SDSPAGE followed by staining with Coomassie Brilliant Blue. The protein concentration was measured according to the Bradford method (1976) using bovine serum albumin as a standard.

Western blot analysis - Western blot analysis was performed as described by da Silva Neto et al. (2009). The $P$. brasiliensis chitinases were detected with the anti-PbCTS1r antibody (diluted 1:500 in PBS). The secondary antibody was anti-rabbit immunoglobulin G coupled to alkaline phosphatase. The reactions were developed with 5-bromo-4-chloro-3-indolylphosphate/ nitro-blue tetrazolium (BCIP/NBT). Negative controls were obtained with rabbit preimmune serum.

Enzymatic activity assay - The chitinase activity was determined as described by Selvaggini et al. (2004) with some modifications, using 4-methylumbelliferyl$\mathrm{N}-\mathrm{N}$ '-diacetylchitobiose [trimer; 4-MU-(GlcNAc) $)_{2}$ or 4- methylumbelliferyl-N-N'-N"'-triacetylchitotriose [tetramer; 4-MU-(GlcNAc) ${ }_{3}$ (Sigma-Aldrich) as the substrate. These substrates were employed based on their ability to detect and distinguish exochitinases (chitobiosidases) and endochitinases. Exochitinases release a fluorescent product from only the trimeric substrates and endochitinases can be identified by digestion from the tetramer (Tronsmo \& Harman 1993, Duo-Chuan 2006). 
In a standard assay, $20 \mu \mathrm{L}$ of diluted enzyme solution was incubated with $5 \mu \mathrm{L}$ of $0.4 \mathrm{mM}$ substrate solution and $80 \mu \mathrm{L}$ of $100 \mathrm{mM}$ citrate-phosphate buffer, $\mathrm{pH} 5.0$, at $37^{\circ} \mathrm{C}$ for $30 \mathrm{~min}$. The reaction was terminated with $120 \mu \mathrm{L}$ glycine $/ \mathrm{NaOH}$ buffer, $\mathrm{pH}$ 10.6. After $5 \mathrm{~min}$ of incubation, a reading was taken at $355 \mathrm{~nm}$ excitation and $460 \mathrm{~nm}$ emissions in a spectrofluorometer (SpectraMax $\mathrm{M}^{\mathrm{e}}$, Molecular Devices). One unit of enzyme activity was defined as the amount of enzyme necessary to produce 1 pmol of 4-MU mL ${ }^{-1} \mathrm{~min}^{-1}$.

Quantitative real-time PCR (qRT-PCR) analysis - Total RNAs from P. brasiliensis (isolate Pb01) mycelium, the transition from mycelium to yeast and the yeast cells were extracted with Trizol (Invitrogen). Single-stranded cDNAs were constructed using a reverse transcription system (Promega). As a control for genomic contamination, the reactions were performed in the absence or presence of reverse transcriptase. qRTPCR was performed in duplicate with samples from two independent experiments using the StepOnePlus ${ }^{\mathrm{TM}}$ Real-Time PCR system (Applied Biosystems). The PCR thermal cycling program was 40 cycles at $95^{\circ} \mathrm{C}(15 \mathrm{~s})$ and at $60^{\circ} \mathrm{C}(1 \mathrm{~min})$. The reaction mixture consisted of SYBR green PCR master mix (Applied Biosystems), 10 pmol of each primer and the template cDNA (40 ng) in a final volume of $25 \mu \mathrm{L}$. A melting curve analysis was performed to confirm the amplification of a single PCR product. The data were normalised using tubulin cDNA for each set of qRT-PCR experiments. A nontemplate control was included. A relative standard curve was generated by pooling an aliquot of cDNA from each sample. The cDNA standard was serially diluted 1:5 and a standard curve was generated using four samples from the pooled cDNA. The relative expression levels of genes of interest were calculated using the standard curve method for relative quantification (Bookout et al. 2006). The qRT-PCR primers for each gene were as follows: CTS1 ss 5'CTACTTGTCCGATACTTGGTCC3', CTS1 as 5'GGAGAGGAGCACATTCAGATTC3'; CTS2 ss 5'GTCCCAAAACGCCAGAATG3', CTS2 as 5' TGAGAACGCAACCGATTGAC3'; tubulin: Tub ss 5'ACAGTGCTTGGGAACTATACC3', Tub as 5'GGGACATATTTGCCACTGCC3'.

Comparison of the sequences and inferred phylogeny - The predicted proteins from the PbCTS1 and $39 \mathrm{kDa}$ chitinase ( $P b C T S 2)$ gene sequences, obtained from a search in the $P$. brasiliensis isolate $P b 01$ genome database (BROAD Institute, MIT and Harvard, Cambridge, MA; broad.mit.edu/annotation/genome/paracoccidioides brasiliensis.1/MultiHome.html), were aligned with chitinases from the National Center for Biotechnology Information (NCBI) server (ncbi.nlm.nih.gov) (Altschul et al. 1990). The phylogenetic analysis of the identified chitinases was generated using sequences from 23 complete ascomycete chitinases. A chitinase from Cryptococcus neoformans, a basidiomycete, was used as an outgroup. A phylogenetic tree was constructed by multiple sequence alignments using CLUSTALX (Thompson et al. 1997), generated by the neighbour-joining method (Saitou \& Nei 1987) and visualised using TreeView software (taxono- my.zoology.gla.ac.uk/rod/treeview.html). The robustness of the branches was estimated using 100 bootstrap replicates and indicates the percentage of times that all species appeared as a monophyletic cluster. The alignments of the sequences are shown in Supplementary data.

\section{RESULTS}

Expression and purification of PbCTS1r protein - To express the recombinant protein, the cDNA coding for $P b C T S 1$ was subcloned into the expression vector pET$32 \mathrm{a}(+)$. After induction with IPTG, a $58 \mathrm{kDa}$ recombinant protein was detected in bacterial lysates (Fig. 1A, Lane 2). The fusion protein was purified from bacterial lysates using Ni-NTA and was cleaved with enterokinase (Fig. 1A, Lane 3) to remove the His-Tag, Trx-Tag and S-Tag. The molecular mass of PbCTS1r agreed with the predicted mass of $45 \mathrm{kDa}$. An aliquot of $P b C T S 1 \mathrm{r}$ was used to raise the anti- $P b C T S 1 r$ antibody. The purified recombinant protein was blotted on a nylon membrane and reacted with the antibody (Fig. 1B, Lane 1). No cross-reactivity to the rabbit preimmune serum was detected (Fig. 1B, Lane 2). PbCTS1r showed higher specific activity in the hydrolysis of 4-MU-(GlcNAc) (142.92 U/mg) compared to 4-MU-(GlcNAc) ${ }_{2}(52.32 \mathrm{U} /$ $\mathrm{mg}$ ), indicating the release of multimers of GlcNAc; in this case, specifically a tetramer of GlcNAc.

Characterisation of the P. brasiliensis PbCTS2 novel chitinase - To confirm our hypothesis of a second chitinase encoded by P. brasiliensis (PbCTS2), the protein was partially purified from crude extracts of yeast cells using cation-exchange chromatography. Two protein peaks were detected possessing chitinase activity (Fig. $2 \mathrm{~A})$. The presence of chitinases in these peaks was further confirmed by immunoblotting analysis. Fractions
A

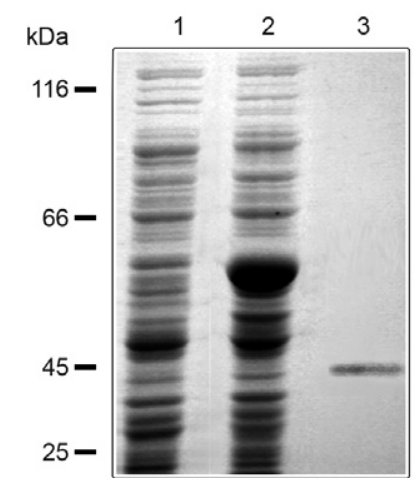

B

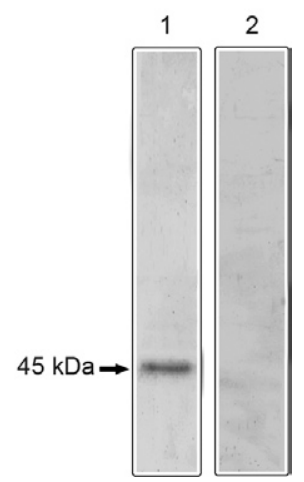

Fig. 1: analysis of the PbCTS1r. A: the proteins were analyzed by $10 \%$ sodium dodecyl sulfate-polyacrylamide gel electrophoresis and stained with Coomassie Brilliant Blue R-250 [Lane 1: total protein from non induced Escherichia coli BL21(DE3)/pLysS containing pET-32a $(+)$; 2: proteins prepared from E. coli BL21(DE3)/pLysS after induction with isopropyl- $\beta$-D-thiogalactopyranoside; 3 : $P b C T S 1 r$ purified]. Molecular masses are indicated at the side; B: Western blot of purified chitinase after incubation with anti-PbCTS1r antibody (Lane 1) and with rabbit preimmune serum (Lane 2). The arrow indicates the overexpressed chitinase protein. 
from the first peak displayed higher activity towards the 4-MU-(GlcNAc) substrate; fractions from the second peak displayed higher activity towards the 4-MU$(\mathrm{GlcNAc})_{2}$ substrate. Three fractions were investigated (Fig. 2B). Two of the analysed fractions (fractions 3 and 5) were collected when the column was washed with buf-

A

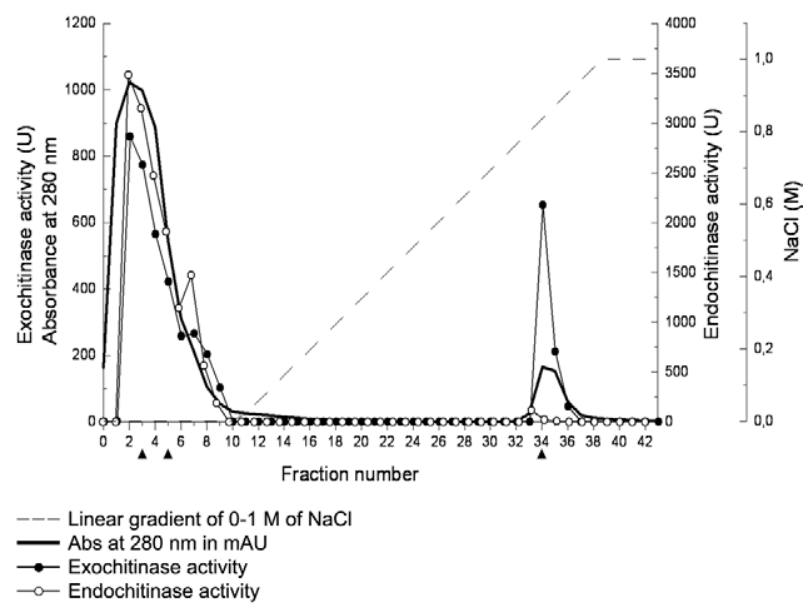

B

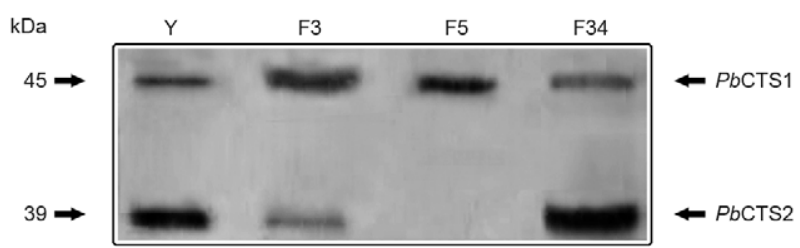

Fig. 2: purification analysis of Paracoccidioides brasiliensis chitinases. A: cationic exchange chromatography profile of yeast crude extract on HPLC and profile of chitinase activity were plotted. Arrowheads indicate fractions 3, 5 and 34; B: three fractions of this purification were analyzed by Western blot using anti-PbCTS1r (Lane Y: crude extract from yeast cells; F3, F5 and F34: fractions 3, 5 and 34 of the cationic exchange chromatography, respectively). The left numbers indicate the size of proteins. In each lane was used $20 \mu \mathrm{g}$ of total protein. $\mathrm{NaCl}$ : sodium chloride. fer A; the other (fraction 34) was collected during the $\mathrm{NaCl}$ linear gradient. In fraction 3, both proteins were detected, with masses of $45 \mathrm{kDa}$ and $39 \mathrm{kDa}$, corresponding to $P b C T S 1$ and $P b C T S 2$, respectively (Fig. 2B, Lane F3). In addition, fraction 3 displayed weaker activity towards the 4-MU-(GlcNAc) ${ }_{2}$ substrate and higher enzymatic activity towards 4-MU-(GlcNAc) $)_{3}$ (Table). Fraction 5, in which only PbCTS1 was detected (Fig. 2B, Lane 3 ), displayed high levels of enzymatic activity when 4-MU-(GlcNAc) was the substrate (Fig. 2A, Table). Both $P b C T S 1$ and $P b C T S 2$ were detected in fraction 34 (Fig. 2B, Lane 4). A higher level of enzymatic activity towards 4-MU-(GlcNAc) ${ }_{2}$ compared to 4-MU-(GlcNAc) ${ }_{3}$ was attributed to $P b C T S 2$ because $P b C T S 1$ showed higher levels of enzymatic activity towards 4-MU-(GlcNAc) (Table). In addition, fraction 34 showed a strong reaction to $P b C \mathrm{TS} 2$, as observed by Western blotting.

Detection of $P$. brasiliensis chitinases - The anti$\mathrm{PbCTS1r}$ antibody was able to detect the presence of $P b C T S 1$ in yeast cell fractions and in different $P$. brasiliensis phases (Fig. 2B, 3A). PbCTS1 was found in the crude extracts of mycelium, the transition from mycelium to yeast and yeast cells (Fig. 3A, Lanes 1-3, respectively). PbCTS1 was not detected in the purified yeast cell wall protein fraction (Fig. 3, Lane 4), but it was present in the secreted protein fraction from the yeast phase (Fig. 3, Lane 5). Serendipitously, the anti-PbCTS1r antibody cross-reacted with the novel $P$. brasiliensis chitinase protein in the immunoblotting (Fig. 3A, Lanes 2-5). PbCTS2 was not detected in the mycelium phase (Fig. 3A, Lane 1). It was detected during the transition from mycelium to yeast (Fig. 3A, Lane 2) and during the yeast phase (Fig. 3A, Lanes 3-5). No cross-reactivity to the rabbit preimmune serum was detected (Fig. 3B). qRT-PCR results examining the transition from mycelium to yeast and the yeast phase corroborate the Western blot results. However, a low Pbcts 2 transcript level was detected in the mycelium phase (Fig. 3C).

Phylogenetic analysis - A search of the P. brasiliensis isolate $P b 01$ genome (BROAD Institute) using BlastP (Altschul et al. 1990) was performed to find the putative gene encoding PbCTS2. In the search, we used

TABLE

Total and specific activity in different protein fractions of the cationic exchange chromatography

\begin{tabular}{lcccccc}
\hline & & \multicolumn{2}{c}{$\begin{array}{c}\text { Total activity } \\
(\mathrm{pmol} / \mathrm{mL} / \mathrm{min})\end{array}$} & \multicolumn{2}{c}{$\begin{array}{c}\text { Specific activity } \\
\left(\mathrm{U}^{b} / \mathrm{mg}\right)\end{array}$} & \multicolumn{2}{c}{$\begin{array}{c}\text { Ratio } \\
\text { Fraction number }{ }^{a}\end{array}$} & $\begin{array}{c}\text { Total protein } \\
(\mathrm{mg} / \mathrm{mL})\end{array}$ & $\begin{array}{c}\text { 4-UM- } \\
(\mathrm{GlcNAC})_{2}\end{array}$ & $\begin{array}{c}\text { 4-UM- } \\
(\mathrm{GlcNAC})_{3}\end{array}$ & $\begin{array}{c}\text { 4-UM- } \\
(\mathrm{GlcNAC})_{2}\end{array}$ & $\begin{array}{c}\text { 4-UM- } \\
(\mathrm{GlcNAC})_{3}\end{array}$ & $\begin{array}{c}\text { 4-UM-(GlcNAC) } \\
4-U M-(G l c N A C)_{3}\end{array}$ \\
\hline Yeast crude extract & 0.852 & 864.17 & 3.170 .11 & 1.014 & 3.721 & 0.27 \\
3 & 0.443 & 773.14 & 3.145 .77 & 1.745 & 7.101 & 0.25 \\
5 & 0.197 & 421.50 & 1.910 .57 & 2.140 & 9.698 & 0.22 \\
34 & 0.0156 & 163.14 & 29.12 & 10.457 & 1.867 & 5.60 \\
\hline
\end{tabular}

$a$ : these fractions refers to Fig. 2; $b$ : one unit of enzyme activity was defined as the amount of enzyme necessary to produce 1 pmol of 4-MU per mL min ${ }^{-1}$; GlcNAC: N-acetylglucosamine. 
PbCTS1 and 18 Hypocrea jecorina chitinase protein sequences (Seidl et al. 2005). We identified five putative $P$. brasiliensis chitinases. Based on the sequence similarity (e-value $\leq 10^{-5}$ ), the size of the open reading frame (ORF) and the size of the protein, a putative gene was identified corresponding to PbCTS2 (broadinstitute.org/ annotation/genome/paracoccidioides_brasiliensis/GeneDetails.html?sp=S7000001961010990).

A phylogenetic tree was constructed with $P b C T S 1$, $P b C T S 2$ and other chitinase genes from ascomycetes available on the NCBI database (Altschul et al. 1990) (Fig. 4). The predicted $P b C T S 1$ and $P b C T S 2$ shared $40 \%$ similarity. Phylogenetic analysis indicated that the paralogues Pbcts1 and Pbcts2 encode two different chitinases in P. brasiliensis.

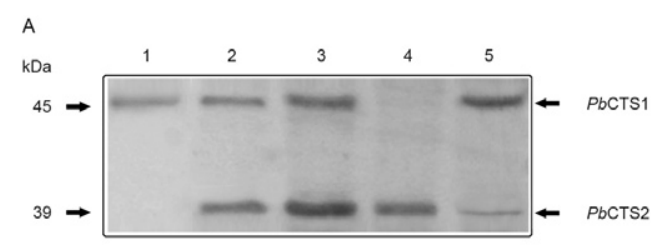

B
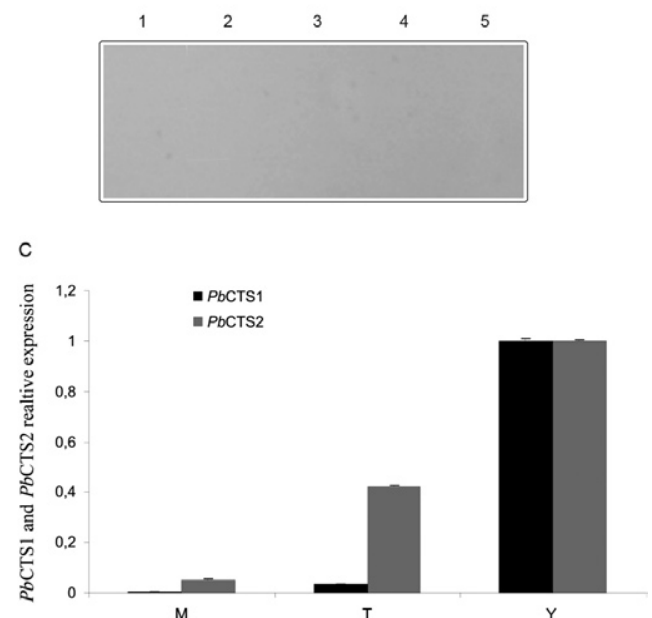

Fig. 3: Western blot and quantitative real-time polymerase chain reaction (qRT-PCR) analyses of Paracoccidioides brasiliensis chitinases. A: the proteins were transferred from sodium dodecyl sulfate-polyacrylamide gel electrophoresis gel to a nylon membrane and incubated with anti-PbCTS1r antibody; B: the cross-reactivity of $P$. brasiliensis proteins was analyzed by Western blotting with rabbit preimmune serum (Lane 1: crude extract from mycelium; 2 : crude extract from mycelium in transition to yeast cells after $24 \mathrm{~h}$ of temperature shift; 3 : crude extract from yeast; 4: yeast cell wall extract; 5: yeast secreted proteins). The numbers on the left indicate the size of proteins. In each lane it was used $20 \mu \mathrm{g}$ of total protein; C: qRT-PCR plot of Pbcts 1 and Pbcts 2 expression levels in mycelium (M), transition from mycelium to yeast after $24 \mathrm{~h}(\mathrm{~T})$ and yeast $(\mathrm{Y})$ cells of $P$. brasiliensis. The primers were as following: CTS1 ss 5'CTACTTGTCCGATACTTGGTCC3', CTS1 as 5'GGAGAGGAGCACATTCAGATTC3', CTS2 ss 5'GTCCCAAAACGCCAGAATG3', CTS2 as 5'TGAGAACGCAACCGATTGAC3'; tubulin: Tub ss 5'ACAGTGCTTGGGAACTATACC3', Tub as 5'GGGACATATTTGCCACTGCC3'. The values of expression of the Pbcts1 and Pbcts 2 were standardized using the values of expression of the constitutive gene encoding to the protein tubulin. The expression level was calculated by relative standard curve method. The standard deviations are presented from two independent experiments.

\section{DISCUSSION}

We have previously characterised the cDNA encoding the Pbcts1 chitinase (Bonfim et al. 2006). To further characterise this chitinase, we expressed the recombinant protein in $E$. coli and raised anti-PbCTS1r antibodies to study the chitinase expression pattern. PbCTS1 was detected in the crude extracts of $P$. brasiliensis mycelium, the transition from mycelium to yeast and yeast cells. This pattern of expression is in accordance with our previous analysis of Pbctsl transcripts in the tested fungal phases (Bonfim et al. 2006). The high expression of $P b C T S 1$ in yeast and the parasitic form of $P$. brasiliensis as well as in the medium of yeast cell culture and in experimental infection conditions (Bonfim et al. 2006) reinforces a role for this protein in the maintenance of the fungal environment.

One study on $P$. brasiliensis strain IVIC $P b 9$ found chitinase activity in the culture medium, but not in the crude protein extracts from yeast cells (Flores-Carreón et al. 1979). In this study, PbCTS1 was detected both in the culture medium and in the crude extracts of yeast cells from isolate $P b 01$, which can be explained by the differences between the isolates and by the use of different substrates to measure chitinase activity.

Bonfim et al. (2006) described the presence of both a glycosaminoglycan attachment site and a laminin G heparin-binding domain in PbCTS1. These domains mediate mycobacterial adhesion to lung epithelial cells and macrophages (Jeffrey 1999) and contribute to cell invasion and systemic dissemination in the host cells (Adams 2004). We found $P b C T S 1$ in the culture medium of yeast, indicating that this protein is secreted and therefore could participate in the maintenance of the fungal environment.

Many chitinases identified to date are secreted, but some are found on the cell wall, as occurs in Candida albicans (Iranzo et al. 2002), Aspergillus fumigatus (Hearn et al. 1998) and Aspergillus nidulans (Yamazaki et al. 2008). PbCTS1 was not detected in the cell wall fraction, suggesting that this chitinase is not involved in yeast cell wall biosynthesis.

Fungi such as C. albicans, A. fumigatus and Saccharomyces cerevisiae encode many chitinases, each possessing diverse chitinolytic activities (Adams 2004). Here, we describe a second chitinase of $P$. brasiliensis, $P b C T S 2$. The five chitinases found in the $P$. brasiliensis isolate $P b 01$ genome database had lengths varying from $26-58 \mathrm{kDa}$; in silico prediction indicated that one of the chitinase genes would generate a $39 \mathrm{kDa}$ protein. Therefore, based on the size of the ORF, the gene sequence and the predicted protein size, we assumed that the $39 \mathrm{kDa}$ gene encoded $P b C T S 2$, which was partially purified in the same fraction as PbCTS1.

The cross-recognition of $P b C T S 2$ with our anti$P b C T S 1 r$ antibody can be explained by the similarity between the two proteins, which are likely to share antigenic determinants. This cross-reactivity allowed us to characterise the activity of a second chitinase. Chitinases of diverse molecular weights have been described in the literature (Seidl et al. 2005). Similar to PbCTS1 and $P b C T S 2$, two other endochitinases of $42 \mathrm{kDa}$ and $37 \mathrm{kDa}$ from Clonostachys rosea (Mamarabadi et al. 


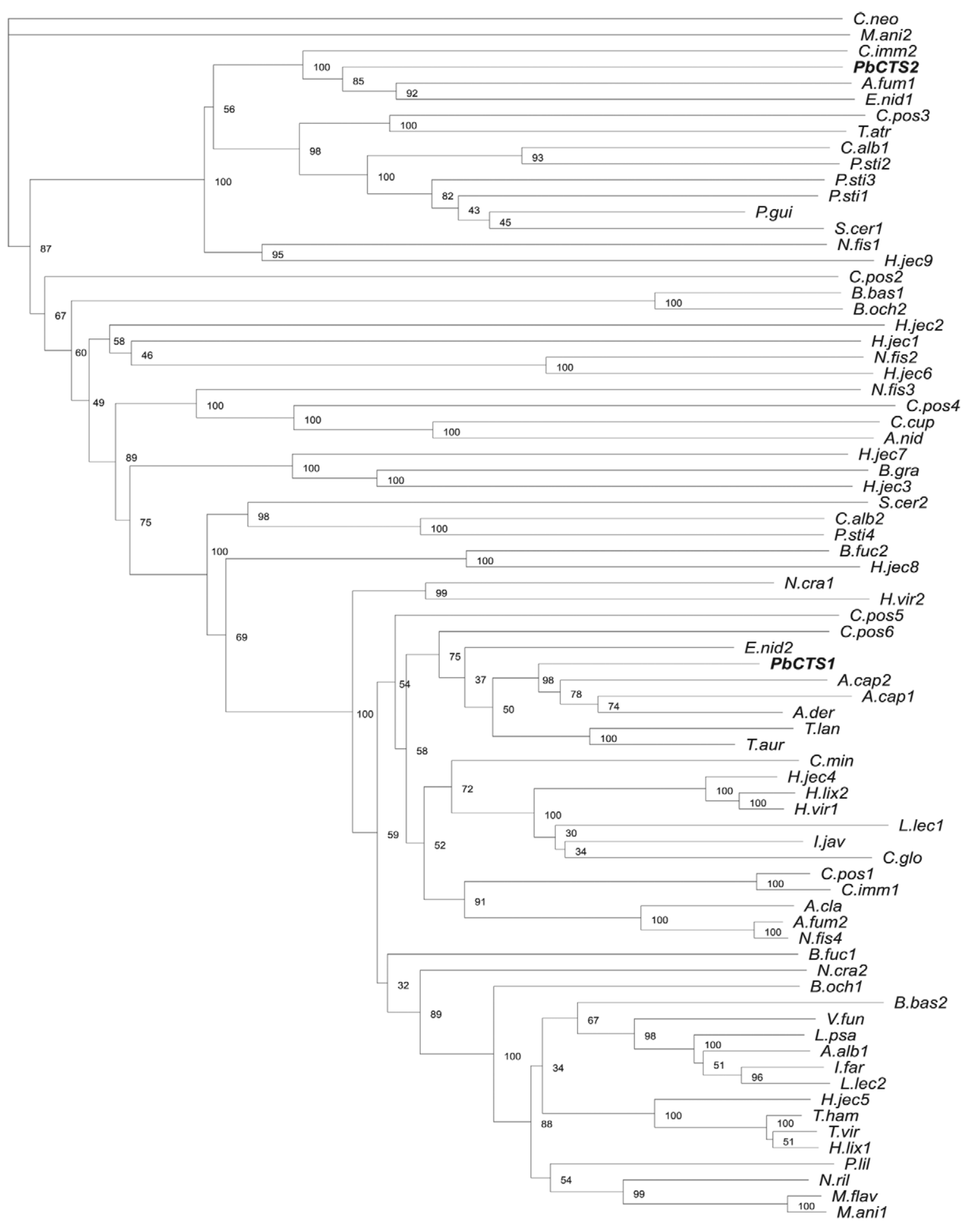

0.1

Fig. 4: phylogenetic tree illustrating the relationship among $P b C T S 1, P b C T S 2$ and others chitinases. Sequences were aligned and subjected to phylogenetic analysis using minimum evolution (neighbour-joining). The numbers on branches indicate bootstrap values obtained for 100 replications. The species (named with binomial name) and the respective GenBank accessions are shown following: Ajellomyces capsulatus 1 (A. cap1) (AAF80370), A. capsulatus 2 (A. cap2) (AAG41982), Aspergillus fumigatus 1 (A. fum1) (AAO61685), A. fumigatus 2 (A. fum2) (AAO61686), Candida albicans 1 (C. alb1) (AAG35112), C. albicans 2 (C. alb2) (AAA68015), Coccidioides immitis 1 (C. imm1) (2204242A), C. immitis 2 (C. imm2) (Q1EAR5), Coccidioides posadasii 1 (C. pos1) (P54196), C. posadasii 2 (C. pos2) (AAO88269), Cryptococcus neformans (C. neo) (XP_572898), Emericella nidulans 1 (E. nid1) (BAA36223), E. nidulans 2 (E. nid2) (BAA35140), Hypocrea jecorina 1 (H. jec1) (DAA05858), H. jecorina 2 (H. jec2) (DAA05857), Metarhizium anisopliae 1 (M. anil) (AAY32603), M. anisopliae 2 (M. ani2) (AAC33265), Neorospora crassa 1 (N. cra1) (XP_965309), N. crassa 2 ( N. cra2) (XP_957924), Paracoccidioides brasiliensis 1 (PbCTS1) (AAQ75798), P. brasiliensis 2 (PbCTS2) (PAAG 03848.1), Sacharomyces cerevisae 1 (S. cer1) (P29029), S. cerevisae 2 (S. cer2) (Q06350). 
2008) have been identified. During the partial chitinase purification, fraction 34 showed a large concentration of $P b C T S 2$, according to the Western blot assays, and a high activity when using the 4-MU-(GlcNAc) $)_{2}$ substrate, which can be attributed to PbCTS2 because only a trace quantity of $P b C T S 1$ was detected in that fraction. In addition, $P b C T S 1$ has a higher enzymatic activity towards 4-MU-(GlcNAc) ${ }_{3}$ than towards 4-MU-(GlcNAc) ${ }_{2}$. Nevertheless, the activity towards 4-MU-(GlcNAc) in fraction 5 and the lack of a visible signal for PbCTS2 in the Western blot could be attributed to other $P$. brasiliensis chitinases present in those fractions.

Although $P b C T S 2$ was not detected in mycelium by Western blot analysis, a low expression level was detected by qRT-PCR, presumably due to the high sensitivity of the technique or post-transcriptional regulation of the protein. PbCTS2 was detected in all of the analysed protein extracts from yeast cells. Because $P b C T S 2$ is expressed in the cell wall, unlike $P b C T S 1$, it may have a role in yeast cell wall biosynthesis and structural maintenance. In addition, the presence of the $39 \mathrm{kDa}$ chitinase during the transition from mycelium to yeast and in the extracellular medium of yeast cells suggests a role in the maintenance of the fungal environment.

The phylogenetic analysis of $P b C T S 1$ and $P b C T S 2$ indicated that they clustered separately and could have different functions. This is similar to chitinases of Emericella nidulans (E. nid 1 and E. nid 2) and Coccidioides immitis (C. imm 1 and C. imm 2). Fungal chitinases can play multiple and diverse roles (Duo-Chuan 2006). During evolution, $P$. brasiliensis could have acquired the paralogues Pbcts1 and Pbcts 2 to grow and survive in different environments in both saprophytic and parasitic phases.

\section{ACKNOWLEDGEMENTS}

To Dr Juliano Tomazzoni Boldo, UFRS, for providing critical review of the paper.

\section{REFERENCES}

Adams DJ 2004. Fungal cell wall chitinases and glucanases. Microbiology 150: 2029-2035.

Altschul AF, Gish W, Miller EW, Myers EW, Lipman DJ 1990. Basic local alignment search tools. J Mol Biol 215: 403-410.

Barrett D 2002. From natural products to clinical useful antifungals. Biochem Biophys Acta 1587: 224-233.

Binod P, Sukumaran RK, Shirke SV, Rajput JC, Pandey A 2007. Evaluation of fungal culture filtrate containing chitinase as a biocontrol agent against Helicoverpa armigera. J Appl Microbiol 103: 1845-1852.

Bonfim SM, Cruz AH, Jesuino RS 2006. Chitinase from Paracoccidioides brasiliensis: molecular cloning, structural, phylogenetic, expression and activity analysis. FEMS Immunol Med Microbiol 46: 269-283.

Bookout AL, Cummins CL, Mangelsdorf DJ, Pesola JM, Kramer MF 2006. High-throughput real-time quantitative reverse transcription PCR. Curr Protoc Mol Biol 15: 1-28.

Bradford MM 1976. A rapid and sensitive method for the quantitation of microgram quantities of protein utilizing the principle of protein-dye binding. Anal Biochem 72: 248-254.

Dahiya N, Tewari R, Hoondal GS 2006. Biotechnological aspects of chitinolytic enzymes: a review. Appl Microbiol Biotechnol 71: 773-782. da Silva Neto BR, de Fátima da Silva J, Mendes-Giannini MJ 2009. The malate synthase of Paracoccidioides brasiliensis is a linked surface protein that behaves as an anchorless adhesin. BMC Microbiol 9: 272.

de Agostino Biella C, Uecker M, Fernandes da Silva M, Barbosa JE, Silva CL, Crott LS 2006. Investigation of the role of complement and complement receptors in the modulation of $\mathrm{B}$ cell activation by a Paracoccidioides brasiliensis cell wall fraction. Clin Immunol 118: 324-331.

Duo-Chuan L 2006. Review of fungal chitinases. Mycopathologia 161: 345-360.

Flores-Carreón A, Gómez-Villanueva A, San Blas G 1979. $\beta$-1,3glucanase and dimorphism in Paracoccidioides brasiliensis. Antonie van Leeuwenhoek 45: 265-274.

Hearn VM, Escott GM, Glyn E, Evans V, Adams DJ 1998. Complex chitinolytic system of Aspergillus fumigatus. Microbios 93: 85104.

Henrissat B, Bairoch A 1996. Updating the sequence based classification of glycosyl hydrolases. Biochem J 316: 695-696.

Iranzo M, Aguado C, Pallotti C, Cañizares JV, Mormeneo S 2002. The use of trypsin to solubilize wall proteins from Candida albicans led to the identification of chitinase 2 as an enzyme covalently linked to the yeast wall structure. Res Microbiol 153: 227-232.

Jeffery CJ 1999. Moonlight proteins. TIBS 24: 8-11.

Kanetsuna F, Carbonell LM, Moreno RE, Rodriguez J 1969. Cell wall composition of the yeast and mycelial forms of Paracoccidioides brasiliensis. J Bacteriol 97: 1036-1041.

Laemmli UK 1970. Clevage of structural proteins during the assembly of head of bacteriophage T4. Nature 2227: 680-685.

Lorito M 1998. Chitinolytic enzymes and their genes. In GE Harman, CP Kubicek (eds.), Trichoderma and Gliocladium, 2th ed., Taylor and Francis, London, 73-99.

Mamarabadi M, Jensen B, Lubeck M 2008. Three endochitinaseencoding genes identified in the biocontrol fungus Clonostachys rosea are differentially expressed. Curr Genet 54: 57-70.

Pitarch A, Sánchez M, Nombela C, Gil C 2002. Sequential fractionation and two-dimensional gel analysis unravels the complexity of the dimorphic fungus Candida albicans cell wall proteome. Mol Cell Proteomics 1: 967-982.

Rush CL, Schüttelkopf AW, Hurtado-Guerrero R, Blair DE, Ibraim AF, Desvergnes S, Eggleston IM, van Aalten DM 2010. Natural product-guided discovery of a fungal chitinase inhibitor. Chem Biol 17: 1275-1281.

Saitou N, Nei M 1987. The neighbour-joining method: a new method for reconstructing phylogenetic trees. Mol Biol Evol 4: 406-425.

Seidl V, Huemer B, Seiboth B, Kubicek CP 2005. A complete survey of Trichoderma chitinases reveals three distinct subgroups of family 18 chitinases. FEBS J 272: 5923-5039.

Selvaggini S, Munro CA, Paschoud S, Sanglard D, Gow NA 2004. Independent regulation of chitin synthase and chitinase activity in Candida albicans and Saccharomyces cerevisiae. Microbiology 150: 921-928.

Thompson JD, Gibson TJ, Plewniak F, Jeanmougin F, Higgins DG 1997. The CLUSTALX windows interface: flexible strategies for multiple sequence alignment aided by quality analysis tools. $\mathrm{Nu}$ cleic Acids Res 25: 4876-4882.

Tronsmo A, Harman GE 1993. Detection and quantification of $N$-Acetyl- $\beta$-D-glucosaminidase, chitobiosidase and endochitinase in solutions and on gels. Anal Biochem 208: 74-79.

Yamazaki H, Tanaka A, Kaneko J, Ohta A, Horiuchi H 2008. Aspergillus nidulans ChiA is glycosylphosphatidylinositol (GPI)anchored chitinase specifically localized at polarized growth sites. Fungal Genet Biol 45: 963-972. 
Multiple alignment of the sequences deduced protein chitinases

\begin{tabular}{|c|c|}
\hline Microorganism ${ }^{a}$ & Multiple alignment \\
\hline M. anil & ------- \\
\hline $\begin{array}{l}N . \quad \operatorname{cra2} \\
\text { PbCTS1 }\end{array}$ & 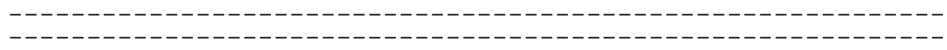 \\
\hline A. $\operatorname{cap} 2$ & 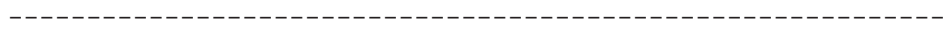 \\
\hline $\begin{array}{l}\text { A. } \quad \operatorname{cap} 1 \\
\text { E. } n i d 2\end{array}$ & 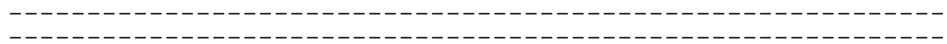 \\
\hline C. posi & 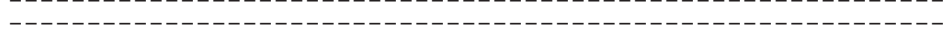 \\
\hline C. imm1 & ------------------------- \\
\hline A. fum2 & ----------- \\
\hline N. Cral & -----------1 \\
\hline $\begin{array}{l}C . \quad \text { a } 1 b 2 \\
\text { A. } \\
\text { fum } 1\end{array}$ & 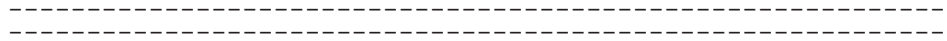 \\
\hline E. nidl & 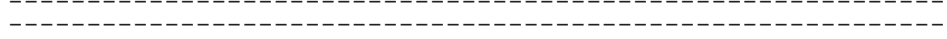 \\
\hline PbCTS2 & 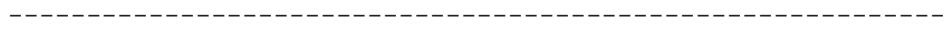 \\
\hline C. $\quad$ imm2 & -------------------------1 \\
\hline $\begin{array}{l}\text { C. } \\
\text { S. } \operatorname{cer} 1\end{array}$ & 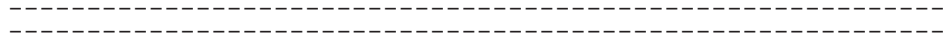 \\
\hline S. cer2 & 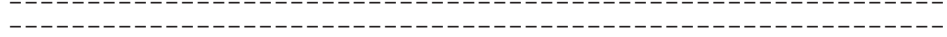 \\
\hline C. neo & ------------------------------------------------------------------ \\
\hline H. jecl & ------------------------ \\
\hline H. jec2 & ------------ \\
\hline $\begin{array}{l}C \cdot \text { pos } 2 \\
\text { M. ani2 }\end{array}$ & ------------------ \\
\hline M. ani2 & ----------------- \\
\hline M. anil & --------------------------1 \\
\hline $\begin{array}{l}N \cdot \operatorname{Cra2} \\
\text { PbCTS1 }\end{array}$ & 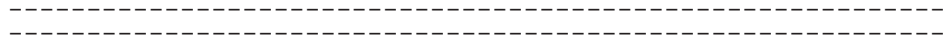 \\
\hline A. $\operatorname{cap} 2$ & 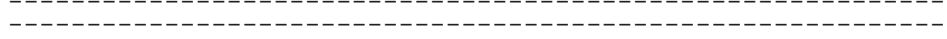 \\
\hline A. $\operatorname{cap} 1$ & 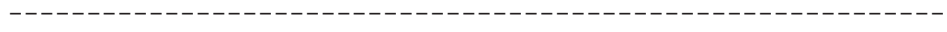 \\
\hline E. $n i d 2$ & 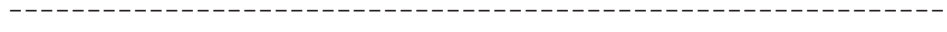 \\
\hline C. posl & 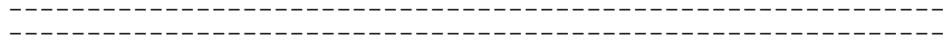 \\
\hline A. fum2 & 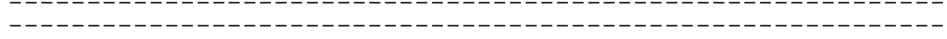 \\
\hline N. Cral & 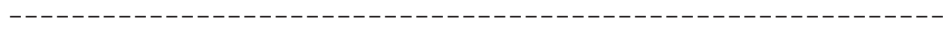 \\
\hline C. $a 1 b 2$ & 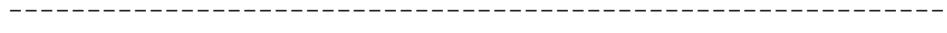 \\
\hline $\begin{array}{l}\text { A. } \operatorname{fum1} 1 \\
\text { E. } \operatorname{nid1}\end{array}$ & 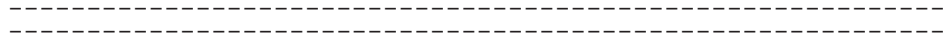 \\
\hline PbCTS2 & 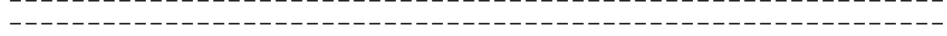 \\
\hline C. $\quad$ imm2 & 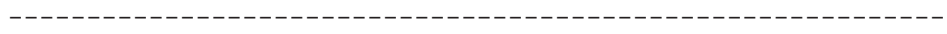 \\
\hline C. $a 1 b 1$ & 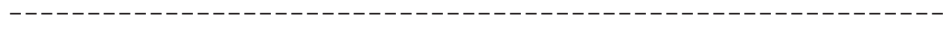 \\
\hline S. cerl & ---------------------- \\
\hline S. cer2 & ---------------------------------- \\
\hline $\begin{array}{l}\text { C. neo } \\
\text { H. jecl }\end{array}$ & 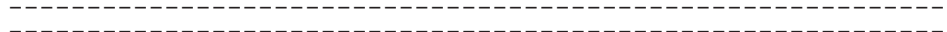 \\
\hline $\begin{array}{l}H . \quad \text { Ject } \\
H . \\
\text { jec } 2\end{array}$ & 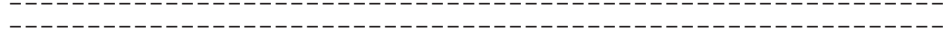 \\
\hline C. pos 2 & ----------- - - - - - - - - - - - - - - - - - - - - - - - - - - - - - - - - - - - - - - - - \\
\hline M. ani2 & ----------------------------------- \\
\hline M. anil & ------------------------------ \\
\hline N. $\operatorname{cra} 2$ & ------------------- \\
\hline PbCTS1 & --------------------- \\
\hline A. $\quad \operatorname{cap} 2$ & 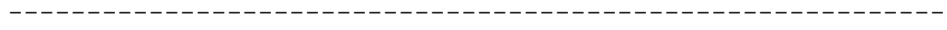 \\
\hline $\begin{array}{l}\text { A. } \quad \text { cap1 } \\
\text { E. } n i d 2\end{array}$ & 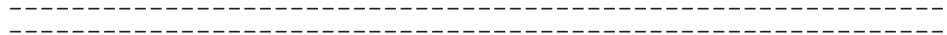 \\
\hline $\begin{array}{l}\text { E. } n i d 2 \\
\text { C. } \operatorname{pos} 1\end{array}$ & 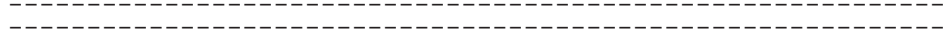 \\
\hline C. $\quad$ imm I & 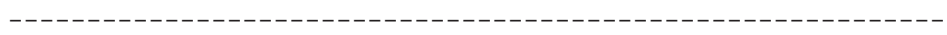 \\
\hline A. fum2 & 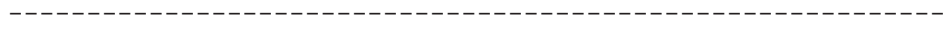 \\
\hline N. Cral & --------------------------------- \\
\hline C. alb2 & 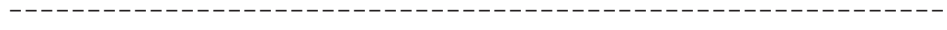 \\
\hline $\begin{array}{l}\text { A. } \operatorname{fum} 1 \\
\text { E. } \operatorname{nid1}\end{array}$ & 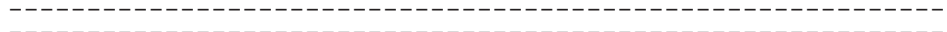 \\
\hline $\begin{array}{l}\text { E. nidl } \\
\text { PbCTS2 }\end{array}$ & 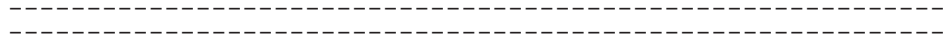 \\
\hline C. imm2 & ----------- - - - - - - - - - - - - - - - - - - - - - - - - - - - - - - - - - - - - - - - - - - \\
\hline C. $a l b 1$ & ---------------------------------1 \\
\hline S. cerl & 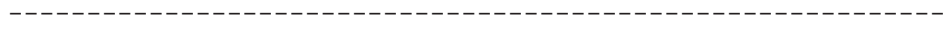 \\
\hline S. cer2 & --------------------------------- \\
\hline C. neo & --------------------------------------- \\
\hline H. jecl & 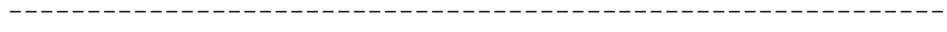 \\
\hline H. jec2 & 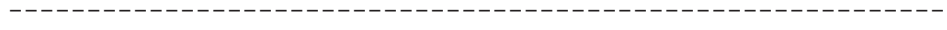 \\
\hline $\begin{array}{l}\text { C. pos2 } \\
\text { M. ani2 }\end{array}$ & 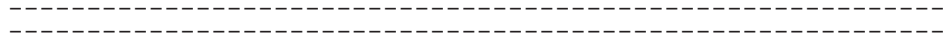 \\
\hline $\begin{array}{l}\text { M. ani2 } \\
\text { M. anil }\end{array}$ & 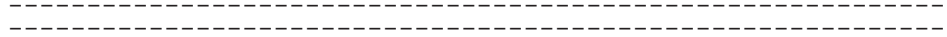 \\
\hline & - \\
\hline PbCTS1 & -------------- - - - - - - - - - - - - - - - - - - - - - - - - - - - - - - - - - - - \\
\hline A. cap2 & ---------------------------------- \\
\hline A. capl 1 & ---------------------------- \\
\hline E. nid2 & ---------------------- \\
\hline C. pos 1 & 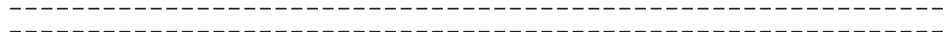 \\
\hline C. imm1 & 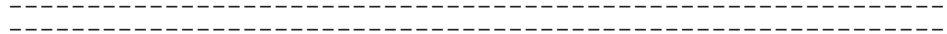 \\
\hline $\begin{array}{l}\text { A. } \\
\text { N.um2 } 2 \\
\text { cra1 }\end{array}$ & 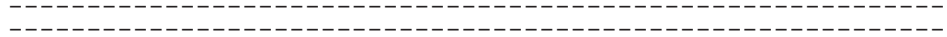 \\
\hline $\begin{array}{l}\text { N. Cral } \\
\text { C. alb2 }\end{array}$ & 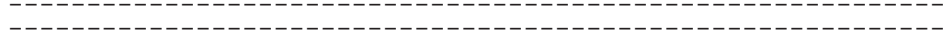 \\
\hline A. fum 1 & 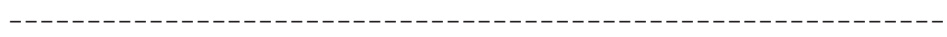 \\
\hline E. nidl & 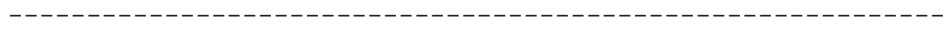 \\
\hline PbCTS2 & 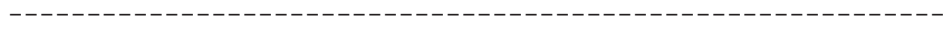 \\
\hline C. $\quad$ imm2 & 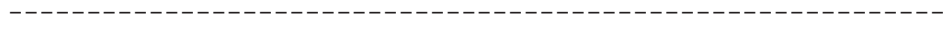 \\
\hline C. albl & 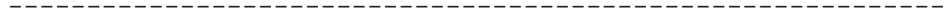 \\
\hline S. cerl & 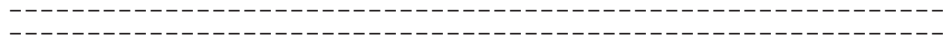 \\
\hline $\begin{array}{l}\text { S. Cer2 } \\
\text { C. neo }\end{array}$ & 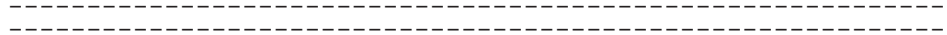 \\
\hline H. jecl & - MAWRLSPRVIRLTTAVGLAHLAQSEAMHEVGNPQC \\
\hline H. jec2 & $---------------M P W I S P G G I A C W L A S A T A I V S F H G V S A T A N E V D A F Q S Q L N L C$ \\
\hline C. pos 2 & 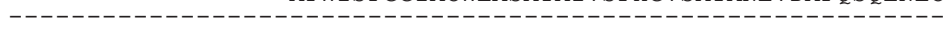 \\
\hline M. ani2 & 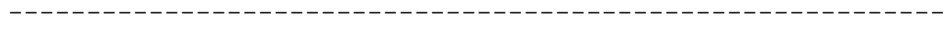 \\
\hline
\end{tabular}


M. $\operatorname{anil}$

$N$. cra2
PbCTS1

A. cap2

A. cap 1

E. nid2
C. posi

C. posi

A. fum2

N. cral

C. alb2

E. nidl

PbCTS2

C. imm2

C. alb1

S. cer2

C. neo

H. jecl

H. jec2

M. ani2

M. anil

N. Cra2

PbCTS 1

A. cap2

A. Cap1

C. posl

C. immI

A. fum2

C. alb2

A. fum1

PbCTS2

C. imm2

C. albl

S. cerl
S. cer2

S. neo

H. jecl

H. jec2

C. pos2

M. anil

N. cra2

PbCTS1

A. cap2

A. cap1

E. nid2
C. posI

C. POsI

C. imm1

N. Cral

C. alb2

E. nidl

PbCTS2

C. imm2

C. albl

S. cerl

C. neo

H. jecl

H. jec2

C. pos2

M. anil

N. Cra2

A. cap2

A. cap1

E. nid2

C. posi

C. imm1

A. fum2

C. alb2

A. fum1

PbCTS2

C. $i m m 2$

C. albI

S. cerl

S. Cer2

H. jecl

H. jec2

M. ani2

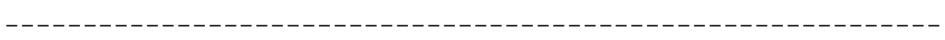

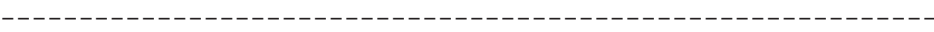
$---1$ $-0$ - -

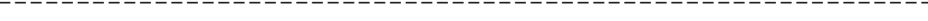
-

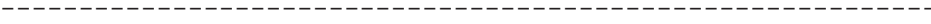
$\begin{array}{ll}-1 & \end{array}$ PSLCVGNGRHEWTAYSSMESLSLCDQPMLFDFAIHVRVDDPESTLRFRACTAANMTERQV PLACSDKSPEQWSVYSSFERLSQCDQPVLFDLAIHTP INDKTNSVLIRACTTS PAAGGSQ -

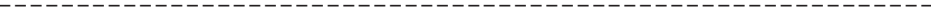

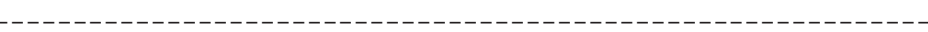
MGPFFLYIGALLFGAVGAVNHGPPEFGSG----YRQGVDFL--------PGRDTA---RSLAWCFVALLLFTALSSVSAA -

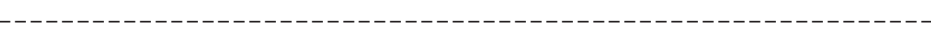
作

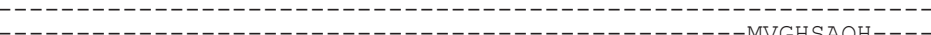
STPAFLSFALLLVSQSSAQGHTAPPGRHRHPRIFK-----------DLQERGQL---LNSTHHGSQHSETHMPGDAHLSSADIARWSPGEAESGLNAVVAFDS-----LRHHL---PMASTVKREAEACGGSFVESKVPLLISQNPGQATAPFGNGLVT I LEGLKEYRQKAV---- - - -

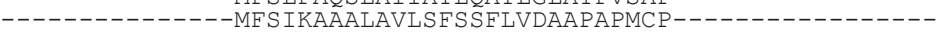
----SVWRSTVWVTSTTTITLPFPSASSSASASSFPAATSTPAADYPVISQASESTPPPP -

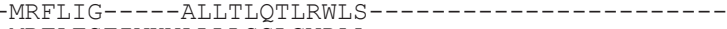
-MRFATSTIVKVALLLSS LCVDAA-------------------$-------M L S$ S IVTCVI PLLVISTPAAAATS------------------

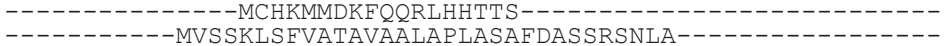

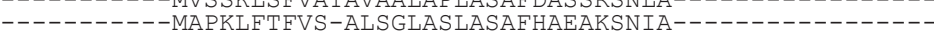

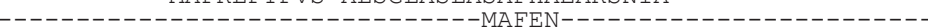
$---------M G L T N I$ LAAF I AVSSLFIQSLALNPYAKSNLA---------------

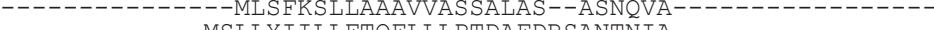
$---------M S L L Y$ I LLFTQFLLLPTDAFDRSANTN IA---- RSKSSLVSHLLILLIFITI I IEMCLYNKI FKNQRS DDIRDN----DERLLPITATTTVVVPMTATRTIWVDSTQLVLGDGGNDGDNDASG ------------GEATDSGENI LFASVHNTVLGLYVGASVDAASAVSALAPGLVDSPYTTGASR----- ATS GCTGDNNIMLGYFDGAVVGTYAGKALS SAT IPS IVDYLLEEDKEQGSAPFG--

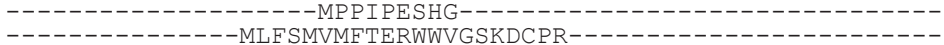

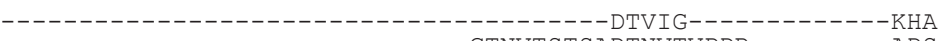
------------------------- GTNVT ST SADTNVTVPDR -------- ADS ------------------------------------ SATEP PS P S PTGNM ------- PHV YEGSCRVRPTPKPPSPSSPIPS--------PPSVYPTRPSP PS PSPSHNM-------SSP --------------------------------------------------- M --------------------------------------- QFQVQS S GN--------- TTV ------------------------------VYYGQG--VNQPRLAEFCAETS ----------------------------------- H IGQA--PNQPRLRH I CANDR ---

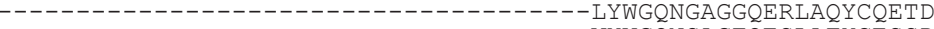

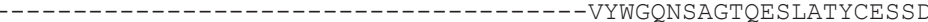
-

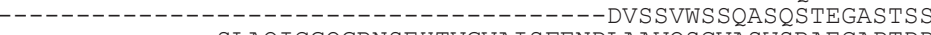
SLAQICGQGRNSEHTVGVAISF ENDAAVQSCVASWSRAECAPTDD

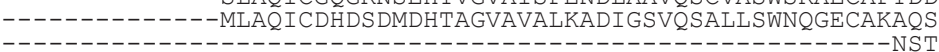


M. anil

N. $\operatorname{cra} 2$

A. cap2

A. cap1

E. nid2

C. $\operatorname{pos} 1$

A. $\operatorname{tum2}$

N. Cral

$\begin{array}{ll}\text { C. } & \text { alb2 } \\ \text { A. } & \text { fum1 } \\ \text { PI } 1 & \end{array}$

E. nidl

PbCTS2

C. imm2

C. Cerl

S. cer2

C. neo

H. jecl
H. jec2

H. jec2

C. pos2

M. anil

N. cra2

PbCTS1

A. cap2

E. nid2

C. pos 1

A. fum2

A. Cral

C. alb2

A. $\operatorname{fum1}$

E. nidl

PbCTS2
C. imm2

C. alb1

S. cer2

C. neo

H. jecl

H. jec2

M. ani2

M. anil

N. cra2

PbCTS1

A. cap2
A. cap1

A. capl

C. posl

A. fum2

N. cral

C. alb2

A. fum1

E. nidl

PbCTS2
C. imm2

C. imm2

S. cerl

S. cer2

H. jecl

H. jec2

M. ani2

M. anil

N. cra2

PbCTS1

A. cap2
A. cap1

A. Cap1

C. pos imm

A. fum2

N. Cral

C. alb2

E. nidl

EbCTS2

C. imm2

C. albl

S. cerl

S. cer2

$H$. jecl

H. jec2

M. ani2
GGYVNAVYFTNWG------- IYGRNYQPADLPASQISH------------------

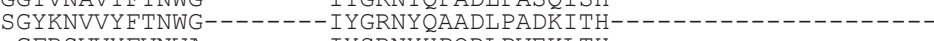

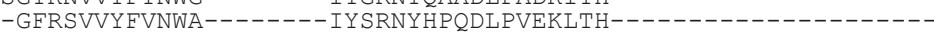
DGFKSVVYFVNWA------ IYGRNYQPQDLPAAKLTH-DGYKS IVYYVNWA------ IYARNYNPQDLPVKKLTH

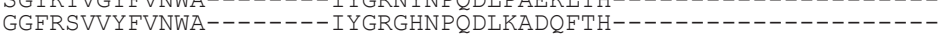
A--VTVVTDDIQA----- IYGRGHNPQDLKADQFTH-SGYRSVVYFVNWA- - - - I I GRNHNPODLPVERLTH

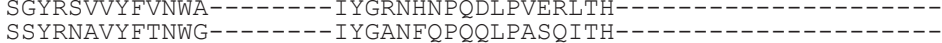
SSYRNAVYFTNWG-------IYGANFQPQQLPASQITH----LD-IINIGEIN----

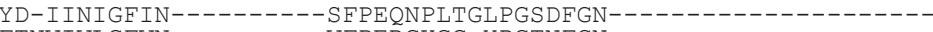

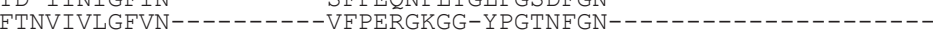

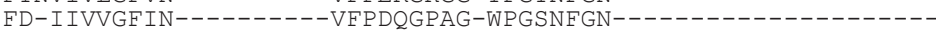
VD-IVLLSFLN------- LFPDP---

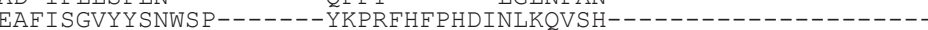

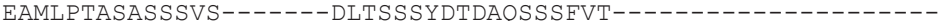
SSE ISTLTDLNI--------WTRSDL PGRPLTRHSHTHLHPRGECKAIKVVPGDSCASI GTTLRE LVI SQVP LPS INAKA SN I SLAEAPGRKAQALDSKVDGKYCKMRT I AAGD SCAS I

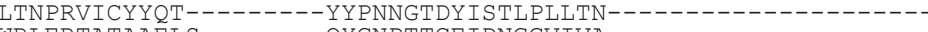
WRLERTATAAELS------QYGNPTTCEIDNGGVIVA

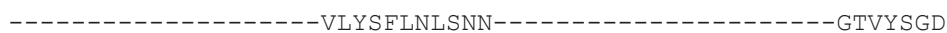
-

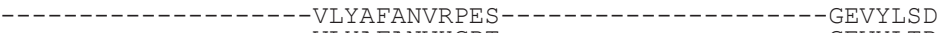
-

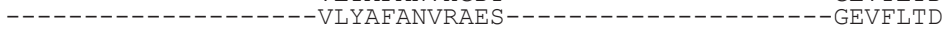
-

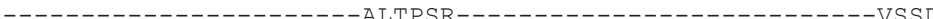
(1) -

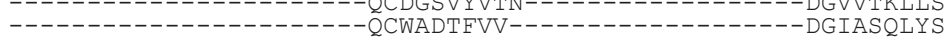

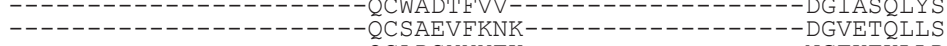
ASKCGVSGANFERYNSYDKRLCSKLAVGKPVCCSPGKLPDLRPKPKPSGECATYTVKSSD AKACKVSVADFFKYNGVKGNGNDWCRKLQAGRNICCSSGSSKPLPEANGDCFSYTIKAGD A

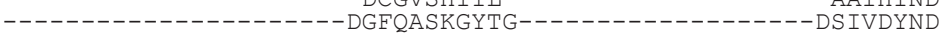

SWADIDKHY----TWSDTDKRY $-1-\cdots-1$ NYADTDKHY

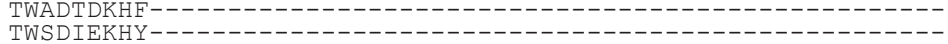
TWSDIEKHY TWKY

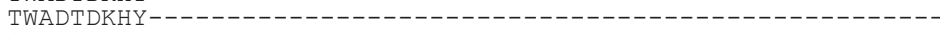
SWADIEKHY -

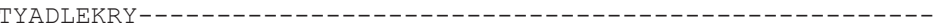

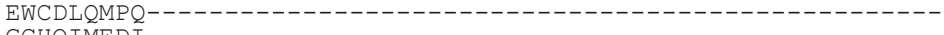
GCHQIMEDI

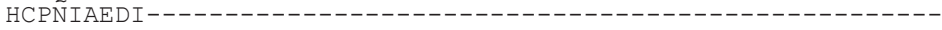

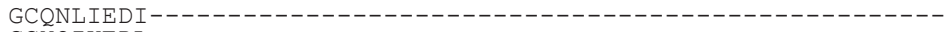

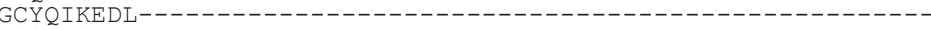

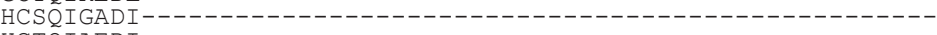

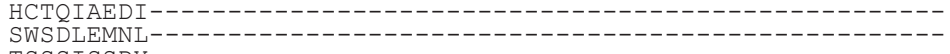

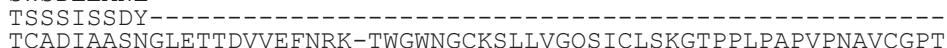
DCSSI GMPWNLTPKDIEGFNQKVTWGWRGCPNLTVGLKICLSKGSPPMPAPVSNAVCGPQ

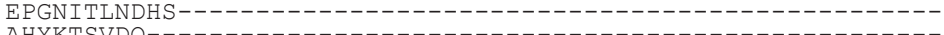
AHYKTSVDQ-

-PNDSWN------DVGNN-------------VYGCVKQLYLLKK--------------PTDSWN------DNGTN------------VYGCVKQLYLLKK------------PTDSWN-PTDSWE-PTDSWS------ETGNN------------VYGCVKQLFLLKK------------PGDKWD------EPGNN------------VYGCIKQMYLLKK------------

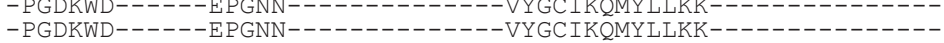
-PGDSWS------DTGNN-------------VYGCIKQLYLLKK--------------PGDSWS------EPGEN-------------AYGCVKQMYLLKK--------------- PSPNQS------ITGN------------------LQQFYEMKK--------------

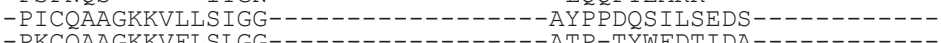

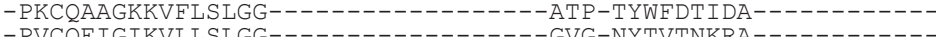
-PVCQEIGIKVLLSLGG-PKCKALGKTILLSLGG -KTCQSLGKTVLLSLGG-----------------GVGDYGFSDVAS-----------

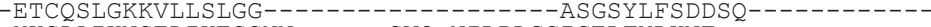
-YKSLAIKNSELIKES SNN------SVQ-NILPLGCI GELFYLKNT-------------PSLSVSQSEASSSTTGVA------TSS----ATVTDSSFSTFAEEPAS--------KPGTVRPESVKDAFELAKLNPCPLNSCCNVWGQCGIDALFCTKADGPTGNPGTAPAGSNG

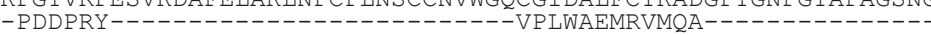
- - DAWGFVRAAYNRGRN-----------TNRQS S GPHPLCTR----------- 


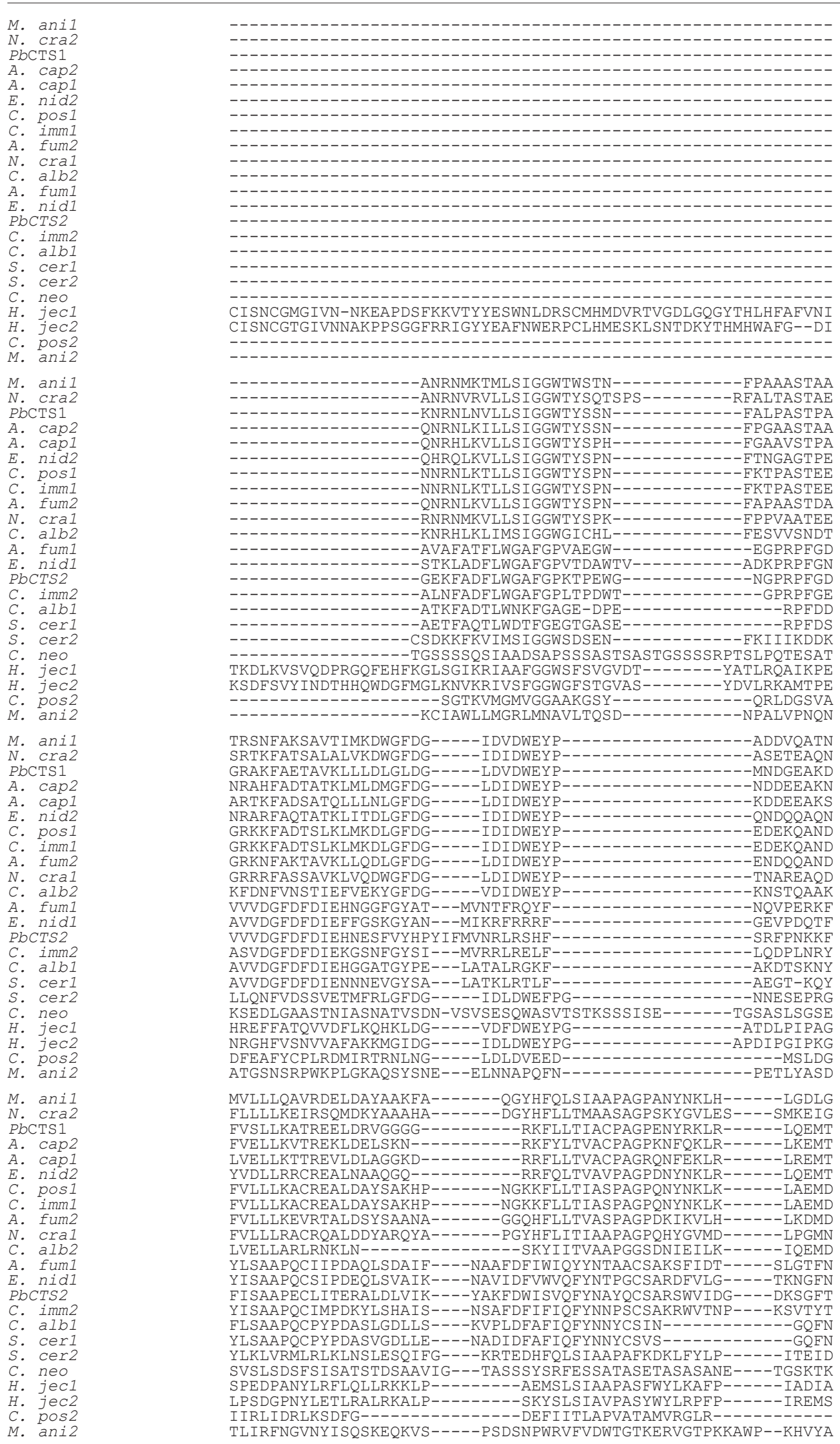




\begin{tabular}{|c|c|}
\hline M. anil & KVLDYINLMAYDFSGS------------- \\
\hline N. cra2 & ETLDFMNLMAYDYAGA -------------------- \\
\hline PbCTS1 & PYLDFYNLMAYDYSGS- - \\
\hline A. cap2 & PYLDFYNLMAYDYAGS- \\
\hline A. capl & PYLDFYNLMAYDYSGS -------------------------------------------- \\
\hline E. $n i d 2$ & PYLDFYNLMAYDYAGS -------------------------------------------- \\
\hline C. posi & KYLDFWNLMAYDFSGS -------------------------------------------- \\
\hline C. imml & 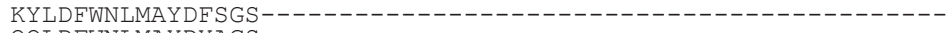 \\
\hline A. fum2 & 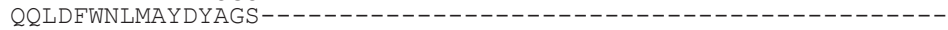 \\
\hline N. cral & PYIDSWHLMAYDYAGS -------------------------------------------- \\
\hline C. $a 1 b 2$ & 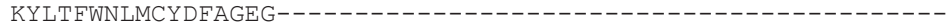 \\
\hline fum 1 & --FDAWVTVLKAS ----------------------------------------------- \\
\hline E. nidl & 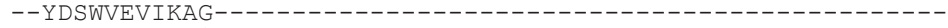 \\
\hline PbCTS2 & 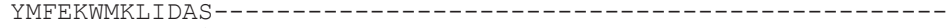 \\
\hline C. $\quad$ imm2 & -- VDDWVKY IRKS ----------------------------------------------- \\
\hline C. $a 1 b 1$ & -- YDTWSKFADSA ----------------------------------------------- \\
\hline S. cerl & 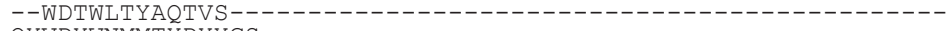 \\
\hline S. cer2 & 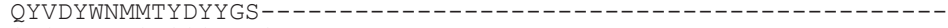 \\
\hline C. neo & 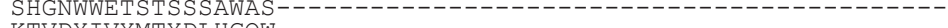 \\
\hline H. jecl & 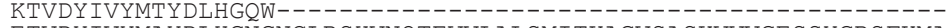 \\
\hline H. jec2 & ETVDYIVYMAYDLHGNGNCLRSHVNQTEVVLALSMITKAGVSASKVVVGESSYGRSFKMA \\
\hline M. ani2 & 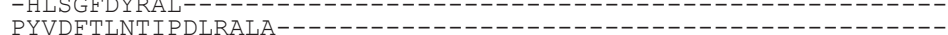 \\
\hline
\end{tabular}
(1) ---------------------------------- WDTVAGHQANLEVSKSDPKS $-------------------------------W D T I A G H Q S N I E I S K S N R N S$ $---------------------------------W D Q T A G H Q A N L Y$ P ST SNPTS ---------------------------------- WDKVSGHMSNVFP STTKPES ---------------------------------- F S S LS GHQANVYNDT SNPLS $-----------------------------------W D S T T$ GHQANLLPS P KNLLT -------------------------------- WS SKTAFHSNLF GNNGD ---

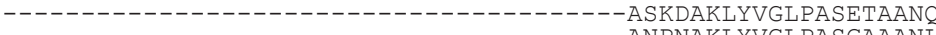
--------------------------------- PNKNI KLFVGVPAT SNIAG ------------------------------ PNKN I KLFLGLPGSASAAG

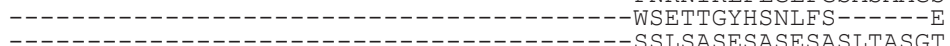
$-----------------------------------D F N S R W A S D G C P K G S C L R S H$ KAGCTGPLCKFTGANGKSEAAAGRCTNARGYLANAE INE I I SKSKGHPKTWYDKDTASDY

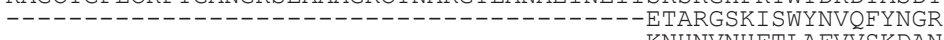

TPFNTDDAVNDYIKGG-VPASKIVLGMPIYGKSFOKTNGI-----------GKPFSGVGTPFSTDRAVTDYIKFG-IPSNKIVLGMPLYGRAFASTDGP----------GTAYSGVGTPVSTEAALNHY I GVGGVPASKIVLGMPLYGRTFANTDGP-----------GTPFQGNGG TPYSTEAALDYYIGVGEVPASKMI LGMPLYGREFADTDGP-----------GTPFTGTGG TPFSTKEAVDYYVGVGKVPPSKLILGMPLYGRTFADTDGP-----------GTPFHGDGG TPFNTVQAVNHY I DAGGVP SNKI I LGMP I YGRAFQNTDGP-----------GRPYSGIG-

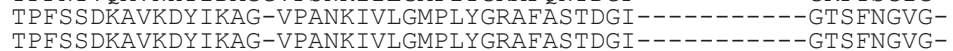
TPFNTQTALDLYRAGG-VPANKIVLGMPLYGRSFANTDGP----------GKPYNGVGTRFNTDQAVRDFVRRG-IPANKIVLGLPLYGRSFEGTDGL-----------GKPYSGIGNSLNASDVVQTYINKG-VHPTKLI LGMPMYGRI FHGVDRPEI---------GIPFTKERK
GYYLTPDEVESLVSTYMDRYPDTFGGIMLWEATASENN-QID--------GAPYADHMK GYYLTPEEVKPLVKKYMDKYPETFGGVMLWEATQARNN-QID--------GVGYNEKIR NYYLDIKEN--YINCFINRHITINKHITINKHITINKH-FYQ-------CINY----NYYLDIKEN--YINCFINRHITINKHITINKHITINKH-FYQ---------CINY-----
EDYLTPGEATKIVSTYMAKYPSTFGGMMVWEATASENN-KLG-------- GLPYADIMK EDYLTPGEATKIVSTYMAKYPSTFGGMMVWEATASENN-KLG---------GLPYADIMK
-- YVDTSKLSSAIEEIKC--DSHFAGVSLWDASGAWLNTDEK-------- GENFVVQVK GYISDTSLLESTIADIAS--SSSFGGIALWDASQAFSN-ELN---------GEPYVEILK TELNGNFAMHYMI DRFGVNSRKLVLGMAAYGRSFH I KDNKFE P FNQNTVLINKIFKGVGK VSVSDS STWPESASVS SAATATTEES STS ISATSTSTSS S--------- S SPTSTLAS
VNMTETLNALAMITKAGVEARQVVVGVASYGRSFEMNDPKCKG------PMCTFTGPQS LVYNDVEWVAYMSDKTKQSRREKWKGLNFLGTVDWAVDLQEFN----VTDHTEPPQGGPG GHMLHPSVYDT I I HQG-WEAERIVIGLLTNPANGSQGYVP-------------METISS TTCGTAYGMQNYAQYSKIKALREAGGDVMLS I GGANNAPLAAS--------CKNVDDLMQ

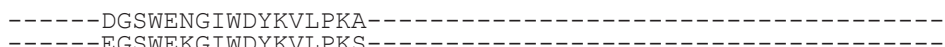

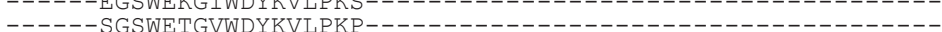

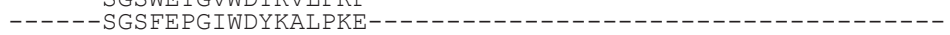

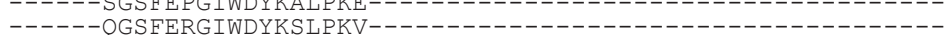

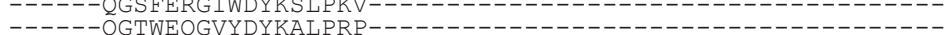
----- GGSWENGVWDYKDMPQQ ------------------------------------- GGSWENGVWDYKDMPQQ -----------------------------------0 GSWENGVWDYKALPQA--------------------------------

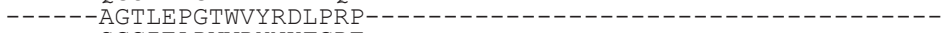
----- S GC IEADVVDYNKFGDT--------------------------------

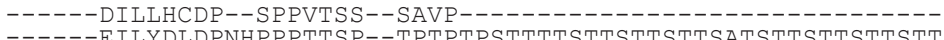
- - EILYDLDPNHPP PTTSP-----EVLLRCDPDPPTSTVTSTISASTSTQTSSQSTTMETKTLSASTTPSSPSTVSPS ----- NVLNQNACVAP S S SATT - - PTKEIDKADGKEG IWPYKNLPKI ------------------------------PTKEIDKADGKEG IWPYKNLPKI $-\cdots$
TLMLGYYPDWSAYYLSPESVDWDR---

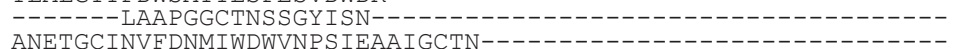
------ VLANVLTKYPSFGGVS--- -------------------------H----YYDIVDNLNLKVLDFDIEG------------------------------- 
Supplementary data

Chitinases of Paracoccidioides • Lidiane Aparecida da Penha Santana et al.

6

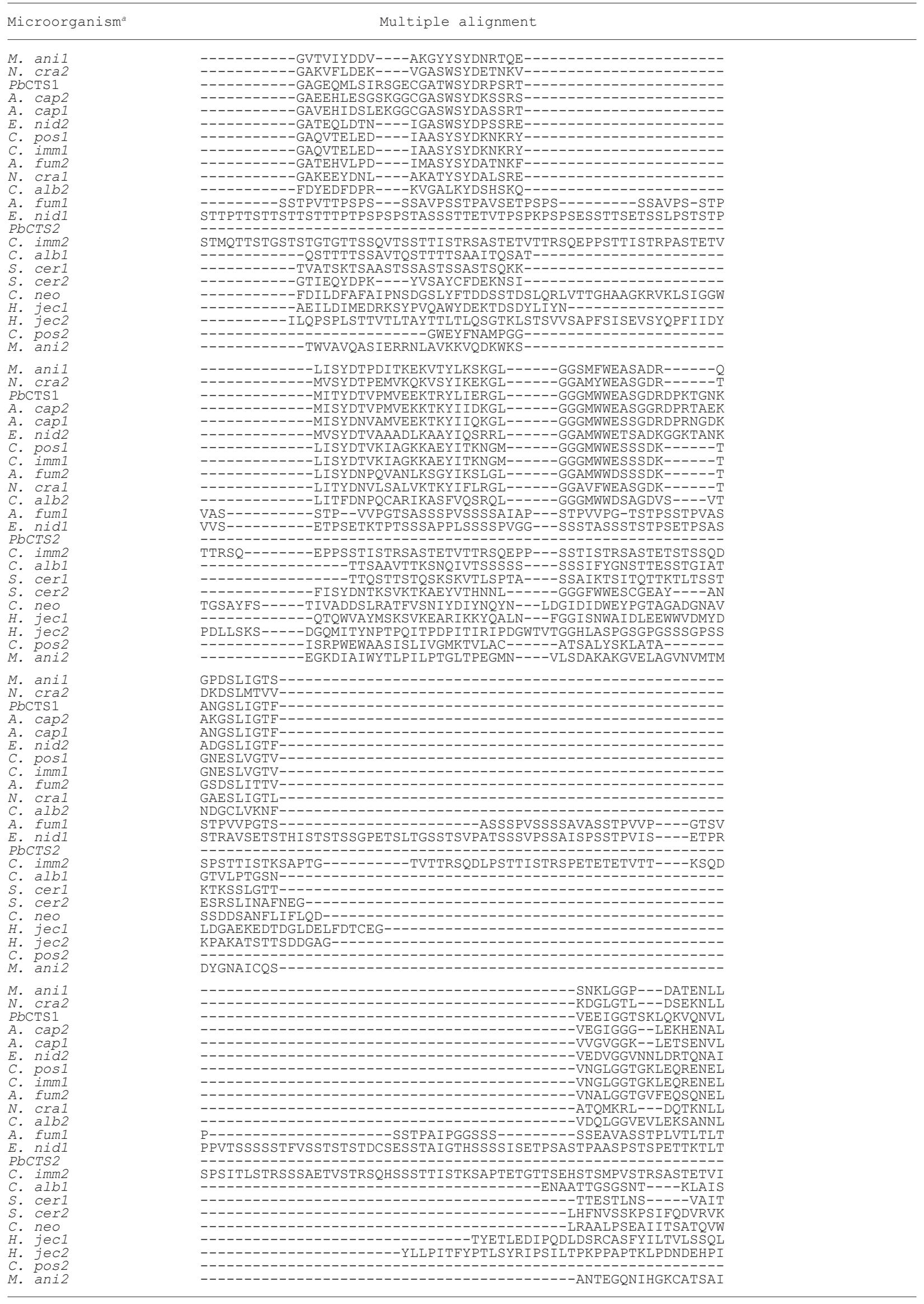


Supplementary data

Chitinases of Paracoccidioides • Lidiane Aparecida da Penha Santana et al.

7

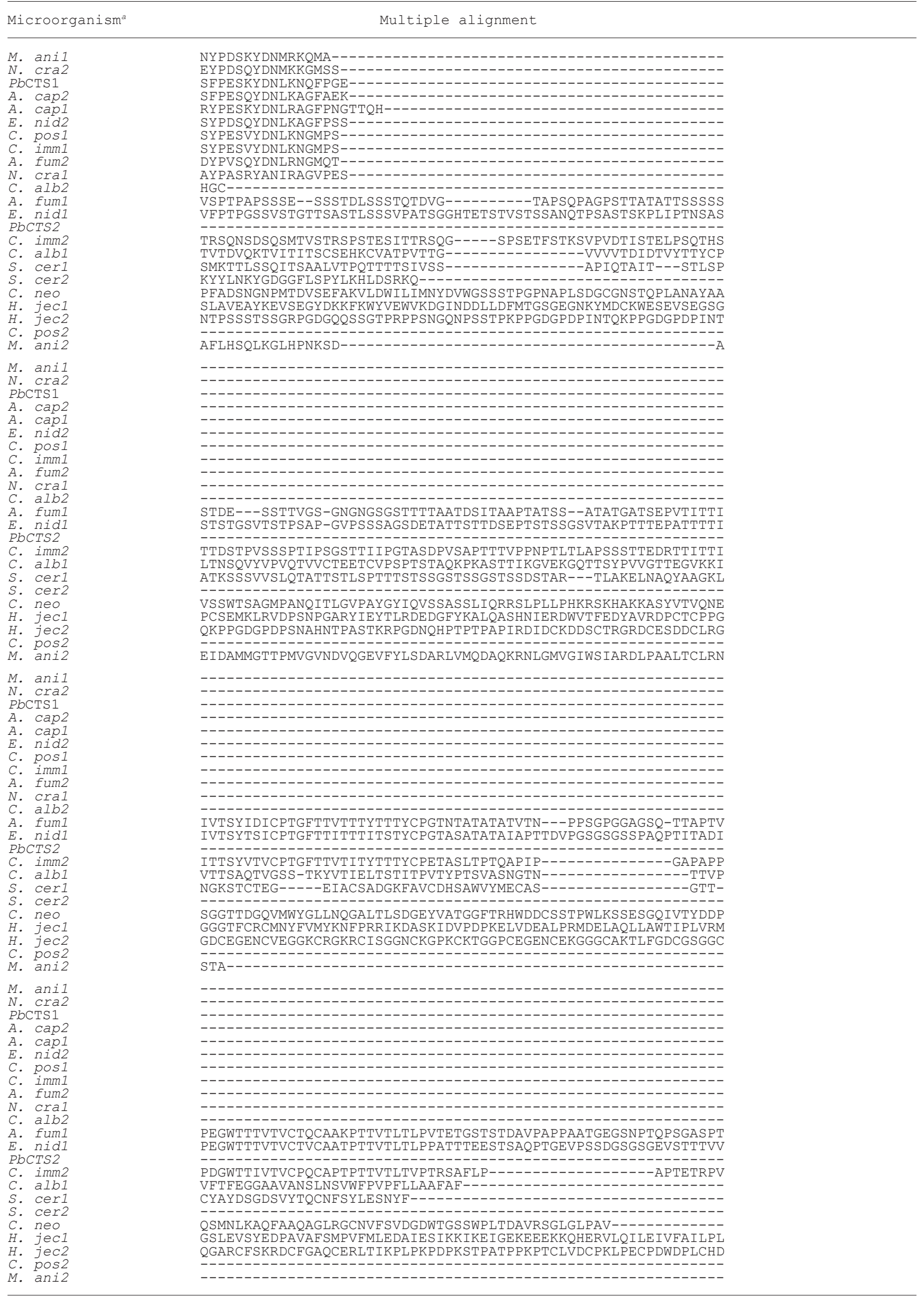


M. $\underset{\text { anil }}{\text { Cra2 }}$

$N$. Cra2
PbCTS1

A. cap2

A. cap1

E. nid2

C. pos

A. $\operatorname{tum2}$

N. Cral

A. alb2

A. fuml

PbCTS2

C. imm2

C. Cerl

S. cer2

C. neo

H. jecl
H. jec2

H. jec2
C. pos 2

$M$. ani2

M. anil

N. cra2

PbCTS1

A. cap2
A. cap1

E. nid2

C. pos 1

A. fum2

N. Cral

C. alb2

A. fum1

E. nidl

PbCTS2
C. imm2

C. albl

S. cer1

S. cer2

C. neo

H. jecl
H. jec2

C. pos 2

M. ani2

M. anil

$N$. Cra2
PbCTS1

A. cap2

A. cap1

E. nid2

C. pos I

A. fum2

N. cral

C. alb2

$A$. fumI

E. nidi

PbCTS 2
C. imm2

C. imm

S. cerI

S. cer2

$C$. neo

H. jecl

C. pos 2

M. ani2

$M$. anil

N. Cra2

Pbcts 1

A. cap2

E. nid2

C. pos 1

A. fum2

N. cral

C. alb2

A. fum

E. nid

C. imm2

C. albl

S. cer

S. cer2

C. neo

H. jec1
H. jec2

C. pos 2

M. ani2

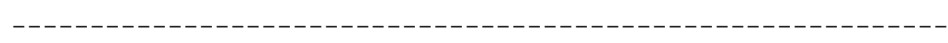
GGNGSFSEEPVPPPAVTQVSTSTEIVTLVRPTSSRPLILG---- TGTVHPSSTLAVKP VVPAPTGNAGDGVPAPGANVGEEYTAAPGSATTSKPLIGGGASGAHTAYPYASSTFHIIP VTVVPVPENPIKNVKPSESGDFVTVTTVAPATVTKTLEYN---1.-NPVDSDVNVQP

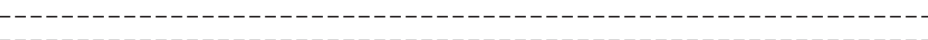
VAEGAAAAFGAASLIARGLALAAELGNGALTVVEIVDDPLSAPFAILGLLIGPLGVRAKG PCPFSACPVYRRPTGKACTTLQTARDCTEFVSSTRVKTKPTTSWSTTTRTLCETMVDCEA

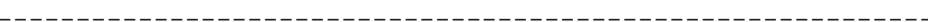

作

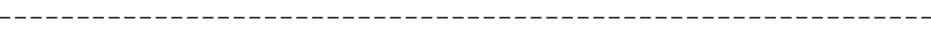
-

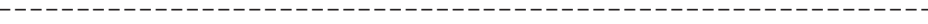
-

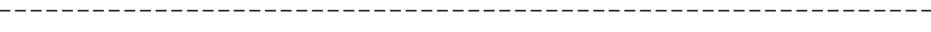
SASAHVPVPSGSGSS---PSGTQGGASPTFTGAGSRYDVVKGVPALVALALSLLAVL--TGGSS-SRSGFRSAADARRALDEGKLKLFSEAFRRKDSLVHMIMKOSKSCKP-..--...--..ADITATTTITTTHTPDPIESVGPAVPYYGVSWSFGEKEKSSMLADEEAYFSALETPMTTT ADITATITITTTHTPDPIESVGPAVPYYGVSWSFGEKEKSSMLADEEAYTSA-DTPMIT

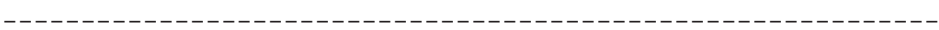

-

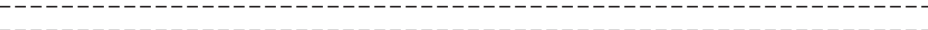
--(1) -

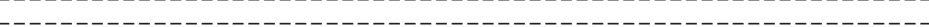

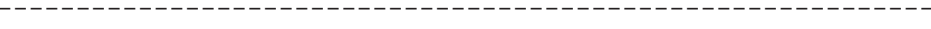
-

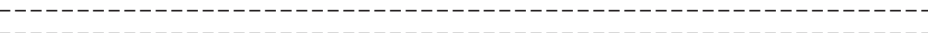

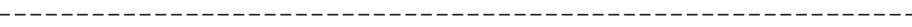
TTTSAEPSTTDDTPTETTADGPTSTVGPNDLVCGFALYAAFYRFDIVKMVGDWVWDDEGH

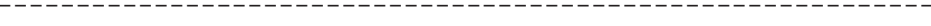

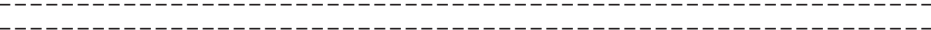
- --

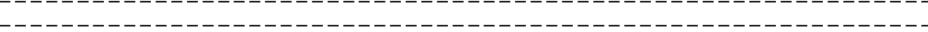

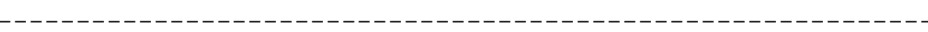
-1
- - -

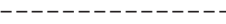
KLKKELKGCGALTGWKWYRRDDGSREARFNLPVFLTAGCVESAIKSAGGPGLSCIFAT-K 
$a$ : the species (named with binomial name) and the respective GenBank accessions: Ajellomyces capsulatus 1 (A. cap1) (AAF80370), A. capsulatus 2 (A. cap2) (AAG41982), Aspergillus fumigatus 1 (A. fum1) (AAO61685), A. fumigatus 2 (A. fum2) (AAO61686), Candida albicans 1 (C. alb1) (AAG35112), C. albicans 2 (C. alb2) (AAA68015), Coccidioides immitis 1 (C. imm1) (2204242A), C. immitis 2 (C. imm2) (Q1EAR5), Coccidioides posadasii 1 (C. pos1) (P54196), C. posadasii 2 (C. pos2) (AAO88269), Cryptococcus neformans (C. neo) (XP_572898), Emericella nidulans 1 (E. nid1) (BAA36223), E. nidulans 2 (E. nid2) (BAA35140), Hypocrea jecorina 1 (H. jecl) (DAA05858), H. jecorina 2 (H. jec2) (DAA05857), Metarhizium anisopliae 1 (M. anil) (AAY32603), M. anisopliae 2 (M. ani2) (AAC33265), Neorospora crassa 1 (N. cra1) (XP 965309), N. crassa 2 (N. cra2) (XP_957924), Paracoccidioides brasiliensis 1 (PbCTS1) (AAQ75798), P. brasiliensis 2 (PbCTS̄2) (PAAG_03848.1), Sacharomyces cerevisae 1 (S. cerl) (P29029), S. cerevisae 2 (S. cer2) (Q06350). 